IZA DP No. 8114

Single Mothers and the Earned Income Tax Credit: Insurance Without Disincentives?

Kartik Athreya

Devin Reilly

Nicole Simpson

April 2014 


\title{
Single Mothers and the Earned Income Tax Credit: Insurance Without Disincentives?
}

\author{
Kartik Athreya \\ Federal Reserve Bank of Richmond \\ Devin Reilly \\ University of Pennsylvania \\ Nicole Simpson \\ Colgate University \\ and IZA
}

Discussion Paper No. 8114

April 2014

IZA

P.O. Box 7240

53072 Bonn

Germany

Phone: +49-228-3894-0

Fax: +49-228-3894-180

E-mail: iza@iza.org

Any opinions expressed here are those of the author(s) and not those of IZA. Research published in this series may include views on policy, but the institute itself takes no institutional policy positions. The IZA research network is committed to the IZA Guiding Principles of Research Integrity.

The Institute for the Study of Labor (IZA) in Bonn is a local and virtual international research center and a place of communication between science, politics and business. IZA is an independent nonprofit organization supported by Deutsche Post Foundation. The center is associated with the University of Bonn and offers a stimulating research environment through its international network, workshops and conferences, data service, project support, research visits and doctoral program. IZA engages in (i) original and internationally competitive research in all fields of labor economics, (ii) development of policy concepts, and (iii) dissemination of research results and concepts to the interested public.

IZA Discussion Papers often represent preliminary work and are circulated to encourage discussion. Citation of such a paper should account for its provisional character. A revised version may be available directly from the author. 


\section{ABSTRACT \\ Single Mothers and the Earned Income Tax Credit: Insurance Without Disincentives?*}

The Earned Income Tax Credit (EITC) is the single most important transfer program in place in the United States. An aspect of the EITC that has received little attention thus far is its role as a public insurance program. Yet, the structure of the EITC necessarily protects its primary class of recipients, unskilled single mothers, against major risks they face to both wages and changes in family structure. Our study provides the first quantitative statement about the insurance provided by the EITC. We study a dynamic model of consumption, savings, and labor supply in which households face wage and demographic risk, but have only limited selfinsurance capacity. We use the model to compare outcomes under the EITC to the counterfactual in which it is completely eliminated. We find that the EITC provides substantial insurance to unskilled single mothers: The program reduces consumption volatility, as measured by the coefficient of the variation, by 12 percentage points or more, even as it allows these households to save less. Importantly, this insurance provision may not be compromising incentives to work: The model suggests that the EITC increases the labor supply of unskilled single mothers substantially at the extensive margin.

JEL Classification: $\quad \mathrm{H} 22, \mathrm{~J} 22, \mathrm{H} 24$

Keywords: taxation and subsidies, labor supply, insurance

Corresponding author:

Nicole B. Simpson

Colgate University

Department of Economics

13 Oak Drive

Hamilton, NY 13346

USA

E-mail: nsimpson@colgate.edu

\footnotetext{
* The authors would like to thank participants at the Federal Reserve Bank of Richmond, SED, Midwest Macroeconomics Meetings in 2012 (Notre Dame), the 2013 AEA meetings in San Diego, Colorado College, and the 2014 lowa Alumni Workshop. Detailed comments from Susan Averett are also appreciated. We thank Roisin McCord for excellent research assistance. The views expressed are only those of the authors and do not reflect those of Federal Reserve Bank of Richmond or the Federal Reserve System. All errors are our own.
} 
IZA Discussion Paper No. 8114

April 2014

\section{NON-TECHNICAL SUMMARY}

In this paper, we evaluate the Earned Income Tax Credit (EITC), which is the largest antipoverty program in the United States to date. The EITC is a fully refundable income tax credit. For low-income households who qualify, the EITC frequently constitutes a significant portion of after-tax wage income. The largest population of EITC recipients is single mothers, which is the focus of our study.

We find that the EITC effectively insures single mothers against volatility in wage income and the risk of needing to care for dependents. That is, the model suggests the EITC may be substantially improving the ability of young unskilled mothers to withstand shocks and smooth consumption over the course of their lives. In fact, our results suggest that the program reduces consumption volatility by 12 percentage points or more. The EITC does this while allowing households to save less and consume more.

Our model also addresses the labor supply effects of the EITC, and finds that it encourages labor force participation among single mothers but reduces hours worked. Given that the EITC compresses earnings volatility while simultaneously increasing labor force participation and mean earnings, our conclusion is that the EITC is insurance largely without disincentives. 


\section{Introduction}

The Earned Income Tax Credit (EITC) is the U.S. federal government's largest cash assistance program for low-income families. In 2010, the federal government in the United States. allocated approximately $\$ 60$ billion through the federal EITC, an amount almost triple that spent on traditional welfare programs in the same year. The EITC is delivered as a fully refundable tax credit, meaning that it is a credit capable of making the tax liability negative for some households. For low-income households who qualify, the EITC frequently constitutes a significant portion of after-tax wage income. In 2008, for example, the EITC benefit among single-headed households with two or more children averaged one-fourth of annual income. ${ }^{1}$

The EITC is far-reaching: In 2008, approximately 24 million households received the EITC, representing 21.3 percent of all U.S. households. ${ }^{2}$ This reflects the broad eligibility criteria of the EITC. For example, families with two children earning up to $\$ 41,646$ (in 2008), an amount relatively close to overall U.S. median household income (\$52,000 in 2008), could qualify for the EITC. The EITC thus plays a significant role in overall public anti-poverty efforts, boosting average incomes significantly for many, especially those who face low expected lifetime earnings.

The EITC's structure will allow it to alleviate poverty and alter labor supply in even a simple static world with no risk to earnings. Not surprisingly, the EITC has been thoroughly and fruitfully studied through the lens of just such models (e.g, Dickert, Houser and Scholz, 1995; and Eissa and Liebman, 1996). But in a world where households face both low average earnings and risk, the EITC may do much more: It may play a major role in insuring households. Our goal in this paper is to evaluate the EITC's role as an insurance mechanism against risks faced by its primary target population: unskilled single mothers. This potentially important dimension of the EITC has, to our knowledge, not been addressed in any existing work.

Two specific features of the EITC allow it to provide substantial insurance. First, the EITC supplements labor income by boosting the incomes of those who, even upon working, would face low labor earnings. As a result, the EITC acts as an insurance scheme over households' effective wages. Moreover, because its generosity depends only on individual-level outcomes, the EITC provides insurance against both idiosyncratic and aggregate wage risk. Given that idiosyncratic labor income risks are large in absolute terms - far larger than aggregate risks (see Storesletten et al., 2004) - the program is thus likely to have quantitatively important insurance benefits for a very large number of households. Notice that the distinction between transitory and persistent shocks is irrelevant in determining eligibility for the EITC. This is because the EITC raises effective wages irrespective of the reason for the value they take in any given period, and for as long as such events occur. By contrast, the effectiveness of self-insurance is decisively

\footnotetext{
${ }^{1}$ Authors' calculations using the 2008 Current Population Survey (CPS).

${ }^{2}$ http://www.eitc.irs.gov/EITC-Central/abouteitc
} 
dependent on the persistence of a given realization of a shock.

Second, the EITC is extremely sensitive to the number of dependent children in a household. ${ }^{3}$ For example, in tax year 2008, households with two or more children earning $\$ 15,000$ could qualify for up to $\$ 4,824$ in federal earned income credits. By contrast, a childless single filer can receive at most $\$ 438$ from the EITC. This feature of the EITC provides protection against the risk of having to solely provide for dependents. Relatively young individuals, especially females, face risk in terms of the number of dependents for whom they will eventually have to provide care. While partially endogenous, the number of dependent children any adult will acquire responsibility for is not perfectly predictable, being the product of shocks to the relationship that produced children and a variety of other factors (including legal considerations) that assign ultimate responsibility or custody of a dependent child to a female parent. ${ }^{4}$

The EITC is therefore likely to play a substantial, and perhaps primary, role in insuring young U.S. households - particularly single mothers - against several of the largest risks that they face. Indeed, single mothers represent the largest recipient group of the EITC: Based on Meyer (2007), single mothers represent 31 percent of EITC recipients and 41 percent of EITC funds. ${ }^{5}$ Furthermore, supplemental wage insurance is likely to be particularly important to the more than one-third of U.S. households headed by someone with at most a high school education (Goldin and Katz, 2008), most of whom will be eligible for a sizable EITC. Indeed, at present, the majority of EITC recipients (61 percent in 2008) are in households headed by an adult without a college education. ${ }^{6}$ This group appears to face sizable labor market uncertainty that is not easily insured (e.g., Huggett et al., 2011; Guvenen et al., 2012), and it appears that these risks have an important component that remains largely unresolved early in their working lives (see e.g. Heathcote et al., 2009).

We construct a model of the EITC in which households face both deterministic (life-cycle) and stochastic variation in their productivity (wages). Furthermore, when young they also face the risk of needing to care for dependents in the future. Households work, consume, and have access to limited self-insurance via savings for future contingencies and a social safety net.

Our assessment of the EITC comes from comparing two environments: that arising from our baseline model in which the EITC is available as it is recently structured (in 2008), and that arising from the counterfactual in which the EITC is eliminated altogether. We evaluate the EITC's capability to insure households by measuring its ability to improve consumptionsmoothing. The benchmark model is calibrated to ensure that it matches a variety of salient

\footnotetext{
${ }^{3}$ For an in-depth description of the EITC, we refer the reader to Hotz and Scholz (2003) or Athreya, Reilly, and Simpson (2010).

${ }^{4}$ This connects our work to the earlier work of Cubeddu and Rios-Rull (2003), who appear to be the first to formally recognize these risks. In fact, they describe families as shocks to individuals, and important ones at that.

${ }^{5}$ These numbers are based on 2005 CPS data.

${ }^{6}$ Authors' calculations using the 2008 CPS.
} 
observations under the current formulation of the EITC. All other dimensions of the household's environment are held fixed.

Given our focus on the EITC's role in insuring households, we require a model in which there is uninsurable uncertainty that is resolved over the life cycle. The inclusion of dynamics and such uncertainty is a key difference between our work and existing work, with two notable exceptions discussed below. Much of the previous literature considers the potential effects of the EITC in a static framework or at least one without risk. In these settings, the EITC can only have a positive effect on labor force participation. However, in our model and in our preferred parameterization, the inclusion of dynamics and risk have the potential to limit changes in labor force participation. On the one hand, it is well-known (e.g., Pijoan-Mas, 2006) that households facing uninsurable risk wish to accumulate precautionary balances, which provides an immediate spur to working irrespective of wages (including the EITC). On the other hand, because the EITC boosts wages, especially for the less productive, it allows for the accumulation of precautionary wealth with less work effort, all else equal. Furthermore, the compression of wages provided by the EITC lowers the risk households face and further reduces the incentive to work. Allowing for such effects may be important in fully characterizing the program's effect on labor force participation and effort for the targeted population.

As noted above, our study contributes by being the first to provide a quantitative statement about the insurance and incentive effects of the EITC in the long run. ${ }^{7}$ The absence of a focus on the consumption-smoothing function of the EITC has meant that almost no work studies the EITC in even a deterministically dynamic setting, let alone one with risk. To our knowledge, there are only two extant examples, both recent. The first is that of Chan (2013). Chan's model is rich in allowing for various options for the worker and in its specification of the set of welfare programs. It follows a standard approach in its estimation of model parameters by specifying a variety of forms of unobserved heterogeneity (preference shifters) to explain the rise in female labor market participation during the 1990s. The second paper is Blank (2012), who follows a very similar strategy to Chan (2013) but stresses the effects of EITC on the transitions to part-time and full-time work. Blank (2012) finds that the elimination of the EITC will lead to reductions in the extensive margin of labor supply by around 5 percentage points, while Chan's (2013) results indicate smaller effects.

While our work clearly benefits from the insights in these papers, it differs in two important ways. Substantively, the key difference between our work and that of Chan (2013) and Blank (2012) is our primary focus on the insurance provided by the EITC against labor market and demographic risk. By contrast, their papers focus exclusively on labor supply alone and do not evaluate EITC's consumption- (and leisure-) smoothing implications, as we do. As a technical

\footnotetext{
${ }^{7}$ We note that our paper is close in spirit to the work of Gruber (2000) and Blundell and Pistaferri (2003) that gauge the consumption-smoothing benefits of other transfer programs (but not the EITC).
} 
matter, a main distinction between our work and theirs is that our focus on insurance leads us to set up markets for self-insurance through savings. Asset markets are a key aspect of our model, given the logic of labor supply near borrowing constraints described above.

Our primary finding is the EITC is particularly effective at providing insurance for its targeted populations. We find that the EITC substantially lowers volatility in consumption: The coefficients of variation for consumption are approximately 12 percentage points lower with the EITC than without. This result is a strong one because it pertains to outcomes that occur for households who enter the economy knowing that EITC no longer exists, and who therefore adjust their savings and consumption decisions to deal with its absence.

In terms of labor supply, the model suggests that the EITC may strongly influence both the extensive and intensive margins of labor supply, with the largest effects on the extensive margin. For example, we find the EITC increases participation for those with one child by approximately 17 percentage points, and for those with two children by 25 percentage points. Effects at the intensive margin are negative but smaller and lie in the neighborhood of 11 to 12 percentage points. In sum, for its intended population, the EITC compresses earnings volatility while simultaneously increasing labor force participation and mean earnings, while diminishing average hours among those who work: It is insurance largely without disincentives.

Our findings are consistent with two important findings from empirical work. First, a general consensus in the empirical literature is that increases in the generosity of the EITC increase labor force participation. For example, Hotz and Scholz (2003) and Eissa and Hoynes (2006) analyze labor market effects of Federal EITC expansions in the 1980s and early 1990s, and they find large positive extensive margin effects for single mothers. Second, empirical work suggests that the many recent changes in the structure of transfer programs to the working poor in general, and not only those limited to the EITC, seem to affect the intensive margin (hours) of labor supply to a smaller degree than the extensive one. This appears particularly true for the group we focus on: single, female-headed households with dependents. Examples include Dickert, Houser, and Scholz (1995) and Eissa and Liebman (1996) who find very little effect on hours worked when analyzing changes in the EITC over time or across U.S. states. This observation has led to a variety of explanations, including "behavioral" ones such as households not being able to understand the nature of EITC or being inattentive with respect to its details, for example. ${ }^{8}$ On the whole, our findings indicate that the EITC, relative to its complete absence, may be a powerful force in driving insurance, consumption, and labor supply for unskilled single

\footnotetext{
${ }^{8}$ But, as Hotz and Scholz (2001) note, the EITC's structure lends itself to compliance: "Compared to alternative delivery mechanisms, the EITC is inexpensive to administer. Most EITC recipients would be required to file a tax return even in the absence of the credit, so the marginal cost of obtaining the EITC is simply the small cost of filling out Schedule EIC. The cost to the IRS is also quite small. The entire IRS budget is roughly $\$ 8$ billion and the IRS serves roughly 120 million individual taxpayers and 15 million corporations." More recently, in a randomized experiment, Chetty and Saez (2013) find little evidence that providing specific details about the EITC changes earnings behavior the following tax year.
} 
mothers.

Two comments are in order. First, our approach differs from earlier empirical work. Instead of studying more incremental changes in the EITC as empirical work has so far been forced to exploit, we take advantage of the fact that our model allows us to compare the EITC to the polar case in which the EITC is completely eliminated. It is this counterfactual that will provide our answer to the question of how the EITC matters. ${ }^{9}$ Second, as we have stressed, ours is a long-run analysis for a cohort of unskilled mothers who understand that with the EITC, the wage risk they face is substantially mitigated. By contrast, empirical work that exploits cross-state variation necessarily assesses the transitional effects of changes in the EITC.

The remainder of the paper is organized as follows. In Section 2, we describe the main empirical facts of the EITC program relevant for our inquiry. Section 3 then lays out our quantitative model, while Section 4 presents the details of the parameterization. Section 5 contains the results, and Section 6 concludes.

\section{EITC and Marginal Income Tax Rates}

The EITC is structured in three phases: in the phase-in period, the credit increases with earnings; in the plateau period, the credit reaches a maximum and levels off; and in the phaseout period, the credit falls as the claimant's earnings rise. In Figure 1, we plot the amount of federal EITC that single and married households receive across various income levels (in 2008). ${ }^{10}$ As is clearly seen, the EITC significantly varies with children: The federal credit can represent up to 34 and 40 percent of income for filers with one and two or more children, respectively. Notice that the slope of the EITC function is steeper in the phase-in range than in the phase-out range. That is, an additional dollar of earned income rewards households in the phase-in region more by giving them a credit, which can range from $\$ 0.07$ (for childless singles) to $\$ 0.40$ (for married couples with two children). In the phase-out range, an additional dollar of income results in a reduction in the credit, from $\$ 0.07$ (for childless singles) to $\$ 0.21$ (for married couples with two children). In addition, the range of eligible income for the EITC is much larger as the number of dependent children rises and is slightly larger for married couples than for single-headed households.

\footnotetext{
${ }^{9}$ Note that several changes occurred in 2009 to the EITC, including an expansion of benefits to families with three or more children and increases in income eligibility for all household types. For the purpose of this paper, we restrict our analysis to pre-2009 EITC structures.

${ }^{10}$ Note that the EITC was increased for working families with three or more children from 40 percent to 45 percent starting in 2010. That is, the credit rate was increased for larger families.
} 
Figure 1: EITC Structure, 2008

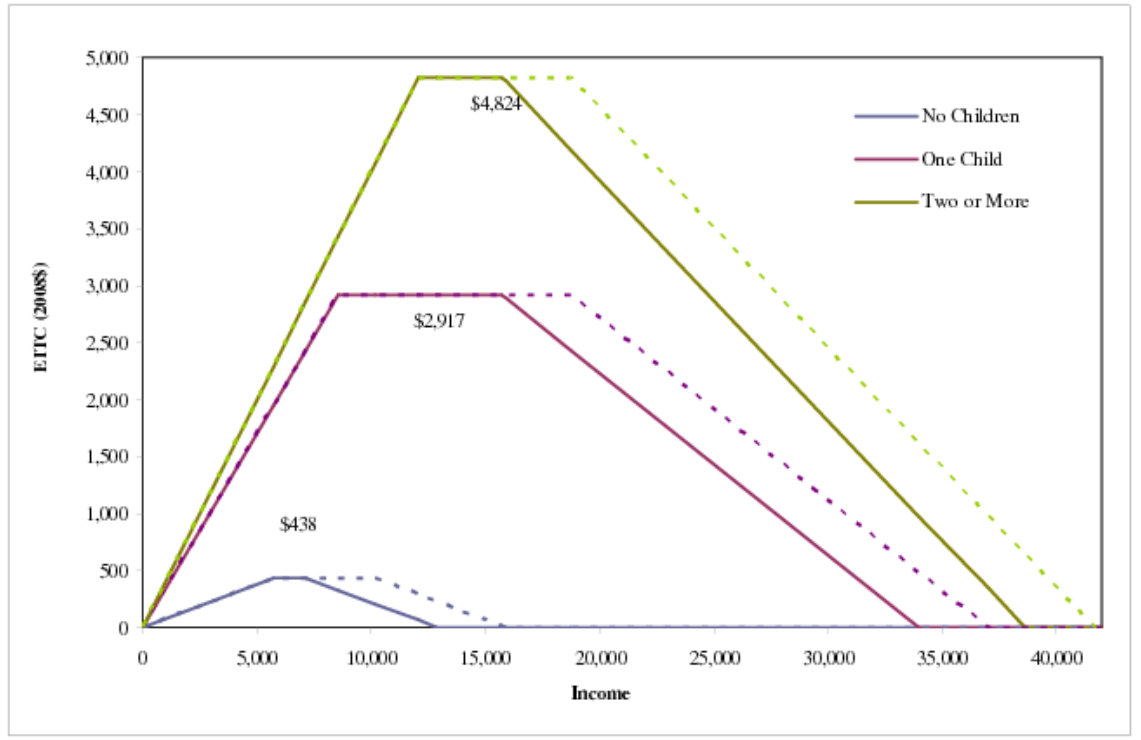

Note: Solid line represents single/head of household filers; dashed line represents married.

We now compare the marginal income tax rates attributed to the EITC by plotting the U.S. income tax schedule with and without the EITC. Using data from TAXSIM version 9.0 from the NBER, we calculate the marginal income tax rates for single households with one and two children (i.e., dependent exemptions) for tax year 2008. In Figure 2, we plot the marginal income tax rates across various income levels for singles earning up to $\$ 100,000$ (in 2008 dollars). Without the EITC, notice that the marginal income tax rate (for single households with two children) is 0 percent for the first $\$ 18,000$ of income, ${ }^{11}$ then jumps to 10 percent for the next $\$ 10,000$ of income (between $\$ 19,000-\$ 29,000$ ), and increases to 15 percent for incomes between $\$ 30,000$ and $\$ 62,000$. As household income approaches $\$ 63,000$, the marginal tax rate increases to 25 percent, and remains there as incomes approach $\$ 100,000$.

The inclusion of the EITC dramatically changes the marginal tax rate schedule for lowincome households with children. For low levels of income, the marginal tax rate is -40 percent for single filers with two children, which represents their EITC phase-in rate. As incomes approach $\$ 13,000$, the marginal tax rate is 0 percent, representing the plateau region of the EITC where households receive the maximum credit. For households with income between $\$ 16,000$ and $\$ 18,000$, the marginal income tax rate is 21 percent, which represents the phaseout rate for the EITC. For households with income between $\$ 19,000$ and $\$ 29,000$, the marginal income tax rate jumps to 31 percent; this represents the EITC phase-out rate plus the 10 percent income tax bracket. For income between $\$ 30,000$ and $\$ 38,000$, single-headed households with

\footnotetext{
${ }^{11}$ For very low income households, dependent exemptions and their corresponding income tax deductions reduce the adjusted gross income to zero. As a result, these households do not hit the lowest income tax bracket of 10 percent.
} 
two children experience a 36 percent marginal tax rate (21 percent phase-out rate plus the 15 percent income tax bracket). For households above $\$ 38,000$, they no longer qualify for the EITC; hence, they return to the standard income tax schedule.

The same general pattern emerges for households with one child, albeit with slightly lower marginal tax rates (in absolute value) since the phase-in and phase-out rates are lower (31 percent and 16 percent, respectively) compared with single households with two children.

Figure 2: Marginal Tax Rates with and without the EITC, 2008
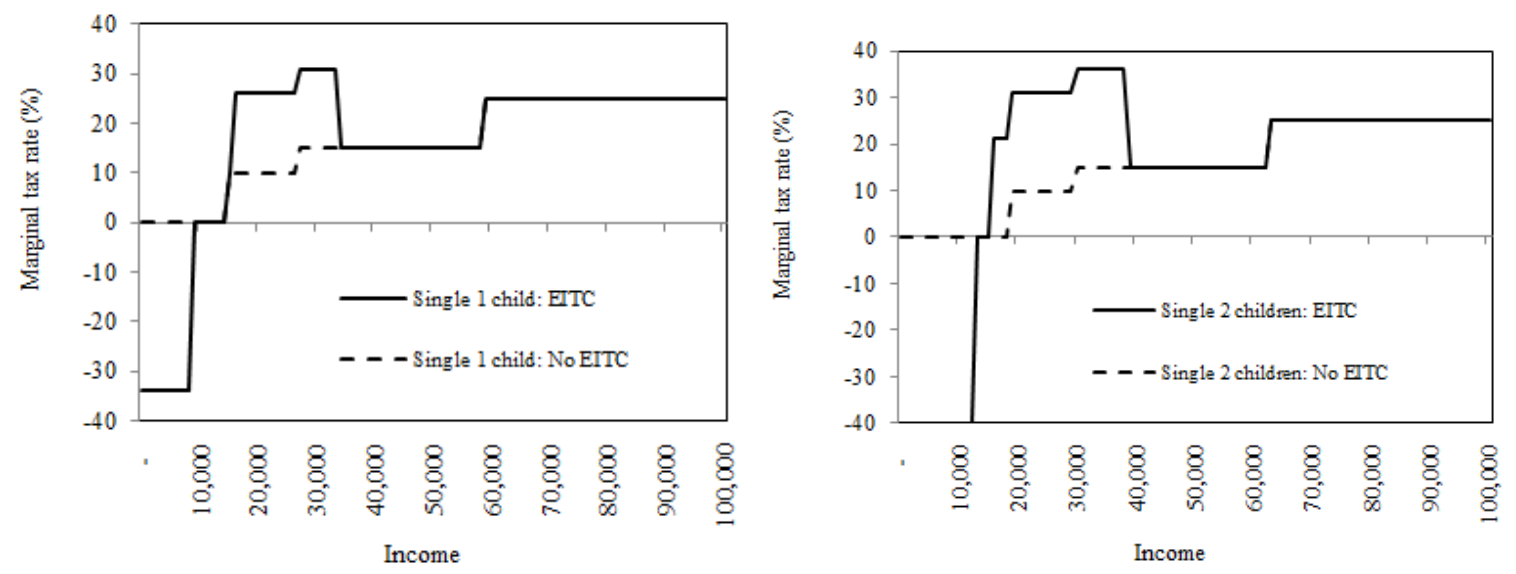

Overall, low-income households with children face very high marginal tax rates due to the phasing-out of the EITC. Studies have shown that the labor supply of low-income households is generally unresponsive to high marginal tax rates (Keane and Moffitt, 1998; Gruber and Saez, 2002). In what follows, our benchmark economy consists of households who face the income tax bracket that includes the EITC. However, we consider a counterfactual experiment in which households experience an income tax schedule without the EITC to measure the extent to which high marginal tax rates due to the EITC are distorting households' decisions.

\section{Model}

The economy consists of a large number of households who enter the model as young, unskilled females. Each individual consumes and works for $J$ periods, and then retires. During working life, household productivity has a deterministically evolving component but is also subject to stochastic shocks. After working life, households enter "retirement," which lasts for $K$ periods. In retirement, households face no further labor market risk and therefore solve a simple deterministic consumption-savings problem. The only constraint faced by retired households is that 
the optimal consumption path must have a present value equal to the present value of resources brought into retirement, inclusive of transfers.

Each period, a new cohort of agents arrives to replace the one that exits. All age-cohorts are therefore of the same size. As already discussed, our analysis will restrict attention to unskilled (i.e., those with a high school degree or less) female-headed households. Each household will solve a completely standard life-cycle household consumption/savings problem. Of course, the environment in which they operate will be substantially enriched relative to standard models to allow for (i) a tax structure that incorporates the EITC, and (ii) demographic and wage risk.

\subsection{Preferences}

At any age $j$, households value both consumption, $c_{j}$, and leisure, $l_{j}$, and discount exponentially using a time-invariant discount factor, $\beta$. Within-period preferences are represented by a standard time-separable Bernoulli CRRA utility function that uses a Cobb-Douglas aggregator over consumption and leisure enjoyed within the period. The Cobb-Douglas specification of the utility function follows the approach taken in Domeij and Floden (2006), which includes many features that are similar to our environment.

Households value resources taken into retirement, $x_{R}$, according to a "retirement felicity function," $\phi\left(x_{R}\right)$. There are fixed costs of labor supply which for convenience are represented in terms of disutility. Agents with strictly positive hours pay costs $\gamma$ denoted by the indicator function $I\left(l_{j}\right)$. That is, letting the maximal leisure available to households be denoted by $\bar{l}$ when $0 \leq l_{j}<\bar{l}, I\left(l_{j}\right)=1$; when $l_{j}=\bar{l}, I\left(l_{j}\right)=0$. The coefficient of risk aversion is defined as $\alpha$, while the elasticity of labor supply is $1-\theta$.

The problem for the household is to choose sequences of consumption $\left\{c_{j}\right\}_{j=1}^{J}$, leisure $\left\{l_{j}\right\}_{j=1}^{J}$, and retirement wealth $x_{R}$ to maximize expected discounted lifetime utility. As discussed at the outset, and as detailed further below, household size will be subject to risk due to uncertainty in the number of dependent children. As a result, household-level consumption expenditures at any age $j$ will translate into effective consumption per adult equivalent according to an agespecific equivalence scale $E S_{j}$, similar to Citro and Michael (1995), Attanasio et al. (2005) and Attanasio et al. (2008). Children do not have a direct effect on utility, other than reducing the effective consumption, according to the equivalence scale, generated by a given level of expenditures.

Let $\Pi\left(\Psi_{0}\right)$ denote the space of all feasible sequences $\left(\left\{c_{j}, l_{j}\right\}, x_{R}\right)$, given initial state $\Psi_{0}$. The household optimization problem is then:

$$
\max _{\left(\left\{c_{j}, l_{j}\right\}, x_{R}\right) \in \Pi\left(\Psi_{0}\right)} E_{0} \sum_{j=1}^{J} \beta^{j}\left(\frac{\left({\frac{c_{j}}{E S_{j}}}^{\theta} l_{j}^{1-\theta}\right)^{1-\alpha}}{1-\alpha}-\gamma I\left(l_{j}\right)\right)+\phi\left(x_{R}\right)
$$


The implied intertemporal elasticity of leisure is then:

$$
\eta^{l}=\frac{1-\theta(1-\alpha)}{\alpha} .
$$

The absence of labor income in retirement implies that the value to a household entering retirement with a given level of wealth, $x_{R}$, is the solution to the following problem. Let $\Pi\left(x_{R}\right)$ be the feasible set of consumption sequences given that a household enters retirement with resources $x_{R}$ :

$$
\phi\left(x_{R}\right)=\max _{\left\{c_{k}\right\} \in \Pi\left(x_{R}\right)} \sum_{k=1}^{K} \beta^{k} \frac{\left[\frac{c_{k}}{E S_{k}} \bar{l}^{1-\theta}\right]^{1-\alpha}}{1-\alpha} .
$$

\subsection{Endowments}

All households are initially identical, enter with zero net wealth, and are endowed in each period with one unit of time. In each period, households receive a wage per unit of labor time as a draw from a distribution, and choose labor supply. Given their labor earnings, households then face a marginal tax (which can take negative values) on labor income and receive transfers.

\subsubsection{Wage Risk}

Given our focus on an a priori similar group of households, all households in the model draw wages from a single stochastic process. ${ }^{12}$ Wages are independent across households. Wages for an adult of age $j$ are denoted by $w_{j}$. It is important to note that we abstract from all other sources of wage income. ${ }^{13}$ Wages follow a stochastic process that disaggregates log wages into three components: the (common) age-specific mean of log female unskilled wages of those with demographic type $i, \mu_{j}$, persistent shocks, $z_{j}$, and transitory shocks, $u_{j}$, that are identically parameterized across all agent types. ${ }^{14}$ Log wages therefore evolve as:

$$
\ln w_{j}=\mu_{j}+z_{j}+u_{j}
$$

where

$$
z_{j}=\rho z_{j-1}+\eta_{j}, \rho \leq 1, j \geq 2
$$

\footnotetext{
${ }^{12}$ Wages are exogenous in our framework. In a setting with no wage uncertainty, Rothstein (2010) finds that the effects of the EITC on wages are important .

${ }^{13}$ It is possible that single-headed households have other adults in the household who contribute to household income. However, based on 2008 CPS data, only 3.3 percent of unskilled single mothers that are EITC recipients have an unmarried partner in the household.

${ }^{14}$ In some places, where no confusion will result, we suppress the dependence of $w_{i j}$ on the agent of type $i$.
} 


$$
u_{j} \sim \text { i.i.d } N\left(0, \sigma_{u}^{2}\right), \eta_{j} \sim \text { i.i.d. } N\left(0, \sigma_{\eta}^{2}\right), u_{j}, \eta_{j} \text { independent }
$$

Households draw their first realization of the persistent shock to wages from a distribution with a different variance than at all other ages. That is,

$$
z_{0}=0, \text { and } \eta_{1} \sim N\left(0, \sigma_{\eta_{1}}^{2}\right)
$$

In subsequent periods, the log of household wages is determined as the sum of the mean of $\log$ wages $\mu_{j}$, the persistent shock $\eta_{j}$ and the transitory shock, $u_{j}$.

\subsubsection{Demographic Risk}

To capture the uncertainty around the future number of household-level dependents, all households face a demographic shock that determines, once and for all, the number of non-adult dependents. We follow Attanasio et al. (2005, 2008) and assume fertility is exogenous. Recent work by Baughman and Dickert-Conlin (2009) indicates that the EITC does not significantly distort the fertility decision for unskilled women. Our approach thus allows us to model risks to household size in a tractable manner. ${ }^{15}$

All households begin working life as single females with no dependents for the first $j_{y}$ periods of life. Between age $j_{y}$ and $j_{y}+1$, households realize the number of children $N_{c, j} \in\{0,1,2\}$ they will have at any age $j$. Their household 'type' $i$ depends on the number of children they have. Note that all agents in the model are childless for the first $j_{y}$ periods but are labeled according to their type after the realization of the demographic shock.

The presence of children enters the household's problem through the income process, the equivalence scale, $E S_{j}=\chi\left(N_{c, j}\right)>1$ and employment cost $\gamma>0$. This equivalence scale takes into account any economies of scale in the production of household utility through consumption expenditures. Given family size, the equivalence scale evolves purely deterministically with age. The income that households earn translate into producing utility through consumption as a function of the household's overall family size. This exposes the household to the need for additional income to maintain a smooth profile of marginal utility across dates and states-ofnature.

\subsection{Asset Market}

A proper assessment of the role of the EITC as an insurance system requires that households in the model be equipped with plausibly available methods of buffering themselves against

\footnotetext{
${ }^{15}$ However, endogeneizing fertility may be an interesting topic to explore in the future.
} 
shocks. Most obvious among these is self-insurance through assets markets, especially those that provide access to risk-free savings. We therefore posit that households have access to a market that allows them to save, or borrow debt up to a limit, $\underline{x}$. A household of age $j$ chooses a risk-free asset position, denoted $x_{j+1}$, to smooth consumption in the face of uncertainty. A strictly positive value for $x_{j+1}$ is interpreted as savings, and earns the risk-free rate of return $R^{f}>0$.To remain close to the literature on life-cycle consumption (e.g. Low, 2005; Attanasio et al., 2008), we assume a small open-economy setting whereby $R^{f}$ is exogenous. This abstraction is appropriate in the present context, as the measure of households most responsive to the policy experiments conducted here hold very low net worth in the aggregate. ${ }^{16}$ If $x_{j+1}<0$, households have borrowed in the current period. When borrowing, the interest rate is denoted by $R^{l}=R^{f}+\psi$, where $\psi$ denotes a per-unit (proportional) transaction cost arising from resources used in intermediation. In what follows, we denote the interest rate by $R$, with the understanding that it represents the values $R^{l}$ and $R^{f}$ as needed.

\subsection{Taxes and Transfers}

At the heart of the model is the mapping that agents face from labor income to their tax liability. In particular, agents face a tax/transfer function $\tau\left(y_{j}\right)$ on all earned income (i.e. labor earnings) $y_{j}$. The function $\tau\left(y_{j}\right)$ can take negative and positive values, where the former are to be interpreted as tax credits. Therefore, given wages $w_{j}$ and labor supply $\left(1-l_{j}\right)$, a household's labor earnings are given by: $y_{j} \equiv w_{j}\left(1-l_{j}\right)$. Net of taxes, or credits, the household's labor income is then $y_{j}\left(1-\tau\left(y_{j}\right)\right)$.

As seen above, the underlying empirical tax function is both nonmonotone and nondifferentiable. An important aspect of our implementation of the EITC in the model is that we will not simplify matters by representing this function via a monotone and smooth approximation, to allow us to exploit interior first-order conditions. Such a step would undermine our ability to give a precise answer to the role played by the EITC. We therefore proceed instead by allowing households to choose both labor hours and assets on very fine grids, and we then compute the exact tax liability using TAXSIM for each combination of resulting income (and household structure). This allows us to accurately capture all of the spikes in marginal tax rates, as documented in Figure 2. While the computation of the model is more burdensome, it will yield a more accurate description of the trade-offs that households face.

Given our focus in this paper on unskilled single mothers, we will not require the EITC to be self-financing. We will not impose a government budget constraint to include revenue from those who finance the EITC, namely high-skill and high-wage households. Given the relatively small share of total taxes paid by low-income households (Bakija and Slemrod (2008)), even

\footnotetext{
${ }^{16}$ Other examples include Livshits et al. (2007), Carroll and Samwick (1997), and Hubbard et al. (1995).
} 
significant expansions in the EITC are unlikely to impose substantial additional tax burdens for this population. Simply put, the EITC is, and likely always will be, a net transfer to a large group of households from a smaller, much higher-income group of households. Given this, the questions of interest are about its effects on labor supply and consumption of the targeted populations.

In addition to the EITC, agents in the model - as in the data - have access to a safety net that reflects the existing U.S. "welfare" system. This system provides transfers to those whose earned income falls below a demographically-dependent threshold, but does so in a way that is means-tested, i.e. depends on household wealth $\left(x_{j}\right)$. This mapping is given as $\tau_{\text {welf }}$ where:

$$
\tau_{w e l f}=\max \left[\bar{c} E S_{j}-x_{j}-w_{j}\left(1-l_{j}\right)\left(1-\tau\left(y_{j}\right)\right), 0\right]
$$

following Scholz and Seshadri (2007). The effect of this function is to guarantee a household always has $\bar{c}$ units of income with which to pay for consumption. It is also evident from equation (8) that households receive lower transfers, ceteris paribus, if they earn more, and in fact, this is one-for-one as long as wealth and earnings collectively exceed the consumption floor. So, given this, there are some immediate disincentives to work and save that exist entirely irrespective of the EITC. The model therefore captures the possibility that overall marginal tax rates, i.e. those beyond what the EITC alone implies, will for some households be extremely high because of the disqualification from safety-net programs. The relevant parameters will be set to match the U.S. tax and transfer system.

After $J$ periods, households enter retirement and receive lump-sum transfers of size $\underline{\tau}^{R}$ in each period that are not means-tested. Households face no risk in retirement. The representation of social insurance after the agent's working life is aimed at capturing the sum of welfare programs, Social Security, and Medicare. Given our focus on transfers early in the working life, this abstraction does not compromise generality.

Let $x_{\tau^{R}}$ denote the present value of all transfers during retirement. That is,

$$
x_{\underline{\tau}^{R}} \equiv \sum_{k=1}^{K} \frac{\underline{\tau}^{R}}{(R)^{k-1}}
$$

Retirement wealth, $x_{R}$, is then the sum of the household personal savings gross of interest, $x_{J+1} R$, and $x_{\tau^{R}}$, and is therefore written as:

$$
x_{R}=x_{J+1} R+x_{\underline{\tau}^{R}}
$$




\subsection{Optimal Household Decisions}

The household's problem is recursive in a state vector that is defined as follows. During working life, a household's feasible set for consumption and savings is determined by its age $j$, beginningof-period net worth $x_{j}$, current-period realization of the persistent shock $z_{j}$, and current-period realization of transitory income $u_{j}$. Once households reach age $J$, the only state that is relevant in determining retirement utility is the level of wealth brought into retirement, $x_{R}$. We begin with retirement.

\subsubsection{Retirement}

In the last period of working life $J$, households evaluate retirement savings according to the function $\phi\left(x_{R}\right)$, and save accordingly. As noted above, households face no risks in retirement, face perfect capital markets, and in particular, have the ability to fully annuitize the flow of retirement benefits. As a result, our setting collapses (during retirement only), to the model of Athreya and Reilly (2009).

In any period $k$ of retirement, the budget constraint is as follows:

$$
c_{k}+x_{k+1}=x_{k} R+\underline{\tau}^{R} .
$$

Given this flow budget constraint, optimal household allocation must satisfy a standard Euler equation:

$$
\frac{c_{k+1}}{c_{k}}=\{\beta R\}^{\frac{1}{\theta(1-\alpha)-1}} .
$$

If we let $\nu=\{\beta R\}^{\frac{1}{(1-\alpha)-1}}$, equation (12) immediately implies that consumption at any date- $k$ (during retirement) becomes:

$$
c_{k}=\nu^{k-1} c_{1} .
$$

The household's lifetime budget constraint pins down the level of consumption that the sequence of retirement consumption levels must start at, given the optimal growth mandated by equation (12). As usual, this is simply seen by iterating on the per-period budget constraint (equation (11)):

$$
\sum_{k=1}^{K} \frac{c_{k}}{R^{k-1}}=x_{R}
$$

where $x_{R}$ is defined in equation (10). As a result, we obtain 


$$
c_{1}=\frac{x_{R}}{\sum_{k=1}^{K} \frac{\nu^{k-1}}{R^{k-1}}} .
$$

The remaining sequence is given by equation (13), which we denote as $\left\{c_{R_{k}}^{*}\right\}_{k=1}^{K}$, which then yields the indirect utility of resources available at the beginning of retirement:

$$
\phi\left(x_{R}\right)=\sum_{k=1}^{K} \beta^{k} \frac{\left[\left(\frac{c_{k}^{*}}{E S_{k}}\right)^{\theta}\right]^{1-\alpha}}{(1-\alpha)} .
$$

\subsubsection{Value Functions}

The finite lives of households makes the construction of the household's optimization problem in recursive terms very straightforward. For ease of notation, we suppress the notation for household type $i$. Beginning with a newly entering adult, for $j=1,2, \ldots \tau_{y}$, its value function is:

$$
W^{Y}\left(j, x_{j}, z_{j}, u_{j}\right)=\max _{x_{j+1}, l_{j}, c_{j}}\left\{\frac{\left(\frac{c_{j} \theta}{E S_{j}} l_{j}^{1-\theta}\right)^{1-\alpha}}{1-\alpha}-\gamma I\left(l_{j}\right)+\beta E_{z_{j+1} \mid z_{j}} W^{Y}\left(j+1, x_{j+1}, z_{j+1}, u_{j+1}\right)\right\}
$$

subject to

$$
c_{j}+\frac{x_{j+1}}{R} \leq w_{j}\left(1-l_{j}\right)\left(1-\tau\left(y_{j}\right)\right)+x_{j}+\tau_{w e l f}
$$

and

$$
x_{j+1} \geq \underline{x}
$$

Since period $j_{y}$ is the final period prior to receiving the demographic shock, expected household continuation utility $V(\cdot)$ is a function of the realized number of dependents. Let $\xi$ denote the probability distribution over the number of dependents. Therefore, we have:

$$
\begin{aligned}
W\left(j_{y}, x_{j_{y}}, z_{j_{y}}, u_{j_{y}}\right) & =\max _{x_{j_{y}+1}, l_{j_{y}}, c_{j_{y}}} \frac{\left({\left.\frac{c_{j_{y}}}{E S_{j_{y}}} l_{j_{y}}^{1-\theta}\right)^{1-\alpha}}_{1-\alpha}-\gamma I\left(l_{j}\right)\right.}{+\beta E_{\xi, z_{j_{y}+1} \mid z_{j_{y}}} V\left(N_{c, j_{y}+1}, j_{y}+1, x_{j_{y}+1}, z_{j_{y}+1}, u_{j_{y}+1}\right)}
\end{aligned}
$$

subject to 


$$
c_{j_{y}}+\frac{x_{j_{y}+1}}{R} \leq w_{j_{y}}\left(1-l_{j_{y}}\right)\left(1-\tau\left(y_{j_{y}}\right)\right)+x_{j_{y}}+\tau_{w e l f}
$$

and

$$
x_{j_{y}+1} \geq \underline{x} .
$$

Once demographics have been assigned, optimal decisions for the remainder of working life will satisfy:

$$
\begin{aligned}
& V\left(N_{c, j}, j, x_{j}, z_{j}, u_{j}\right)=\max _{x_{j+1}, l_{j}, c_{j}} \frac{\left(\frac{c_{j}}{E S_{j}} l_{j}^{1-\theta}\right)^{1-\alpha}}{1-\alpha}-\gamma I\left(l_{j}\right) \\
&+\beta E_{z_{j+1} \mid z_{j}} V\left(N_{c, j+1}, j+1, x_{j+1}, z_{j+1}, u_{j+1}\right)
\end{aligned}
$$

subject to

$$
c_{j}+\frac{x_{j+1}}{R} \leq w_{j}\left(1-l_{j}\right)\left(1-\tau\left(y_{j}\right)\right)+x_{j}+\tau_{\text {welf }}
$$

and

$$
x_{j+1} \geq \underline{x} .
$$

Since households do not have children before age $j_{y}$, and because these children leave the household after age $j_{a}$, we have:

$$
\begin{gathered}
N_{c, j}=0 \text { for } j \leq j_{y} \\
N_{c, j}=N_{c, j_{y}} \text { for } j=j_{y}+1, j_{y}+2, \ldots, j_{a} \\
N_{c, j}=0 \text { for } j \geq j_{a}+1
\end{gathered}
$$

In the final period of working life, period $J$, households make decisions given the continuation value, $\phi\left(x_{R}\right)$.

$$
W\left(J, x_{J}, z_{J}, u_{J}\right)=\max _{x_{J+1}, l_{J}, c_{J}}\left\{\frac{\left(\frac{c_{J}}{E S_{J}} l_{J}^{1-\theta}\right)^{1-\alpha}}{1-\alpha}+\phi\left(x_{R}\right)\right\}
$$

subject to

$$
c_{J}+\frac{x_{J+1}}{R} \leq w_{J}\left(1-l_{J}\right)\left(1-\tau\left(y_{J}\right)\right)+x_{J}
$$

and 


$$
x_{J+1} \geq 0 .
$$

\subsubsection{Optimal Labor Supply}

An insight of recent work on the effects of household-level labor market risk, as developed in papers of Domeij and Floden (2006) and Pijoan-Mas (2006) is the following: In the absence of the complicated incentives created by the EITC, but in the presence of wage risk and low wealth, the equilibrium responses of hours to after-tax wages turn out to be far smaller than what might otherwise be expected for a given underlying elasticity of labor supply. The driving force for this result is that low-wealth households who face binding liquidity constraints (or expect to in the near-future) and uninsurable risk will choose to work to retain borrowing capacity to deal with shocks. This will make labor supply for any group that is well-described by low wealth and limited access to credit relatively insensitive to current productivity.

This logic means that as a quantitative matter, a determinant of the size of the effects of the EITC lies in the proportion of workers located at wealth levels near a borrowing constraint. The relevance of this region of asset holdings for our investigation is clear: Uninsurable idiosyncratic risk and constraints on liquidity have both been consistently estimated to be important and pervasive among the EITC's targeted recipients of young, low-skilled households. For example, the classic work of Hubbard, Skinner, and Zeldes (1995) shows that young, low-skilled households face substantial uninsurable income risk. Jappelli (1990) is also an important reference documenting the importance of binding liquidity constraints for at least 20 percent of US households, with disproportionate portions of the constrained coming from the ranks of the young and poorly educated. Relatedly, Gruber (2001) estimates that nearly one-third of all workers have wealth levels so low that they would be unable to replace even 10 percent of the earnings lost from a typical unemployment spell. Moreover, the bottom quartile of unskilled single mothers has zero net financial wealth and the median single mother has a net worth of approximately $\$ 1,500$ (based on 2007 Survey of Consumer Finances data). A program like the EITC, to the extent that it applies primarily to low wealth households, is likely to operate on a population that is relatively insensitive to variation in wages. As a result, when wages are low, such a program may be potentially quite useful in boosting after-tax household income without dulling work incentives. In other words, single mothers have other reasons to work, and this allows the EITC to enhance their incomes in ways that more closely resemble lump-sum transfers. $^{17}$

\footnotetext{
${ }^{17}$ In a static labor-leisure model, the EITC will increase the marginal value of working (i.e., the after-tax wage rate) which, via a pure substitution effect, encourages labor supply among those receiving a transfer. Nonetheless, the EITC still has the potential to lower labor supply for at least two reasons. First, the same increase in effective wages also generates an income effect that will, all else equal, lower labor supply. Second, households in the phase-out region, who are uniformly low income, experience some of the highest marginal
} 


\subsection{Equilibrium}

We will restrict attention to stationary competitive outcomes, as is standard (and hence omitted). ${ }^{18}$ In particular, all agents view prices as constant for their entire decision horizon, and all aggregate outcomes are those computed from the stationary distribution of households over the state vector. Our aggregate results are thus to be interpreted as summary measures of outcomes for the members of a single large cohort over their entire lifetimes, each of whom optimizes given full knowledge of the EITC regime in place.

\section{Parameterization}

\subsection{Demographics and Preferences}

All households in the model are unskilled (i.e., those with a high school degree or less) and enter the model at calendar age 18. Households work for $J=48$ periods and then enter retirement (after calendar age 65) which lasts for $K=25$ periods. In the first $j_{y}=6$ periods after their entrance into the model, households are single and childless. In model period 7 , they receive a demographic shock $\varepsilon \sim f\left(N_{c, j}\right)$, which is consist with 2008 CPS data indicating that age 25 is when single women are most likely to have their first child. At the end of this period $j_{a}=25$ (calendar age 43), their children leave the household. We set the parameters of the demographic shocks to match the probability for single mothers of having zero, one and two children. Using 2008 CPS data, we find that 62.3 percent of single women have no children, 19.5 percent have one child, and 18.2 percent have two or more children. We set the probability distribution over demographic shocks to match these data.

With respect to preferences, since the decisionmaker has isoelastic (CRRA) preferences over "composite consumption" (in our case the (Cobb-Douglas) aggregate of consumption and leisure seen above), there is a single parameter-the coefficient of risk aversion-to assign. We set $\alpha$ to 3. This implies an elasticity of intertemporal substitution of $1 / 3$. These measures are consistent with Scholz and Seshadri (2007), among others. Within each period, preferences between consumption and leisure are of the Cobb-Douglas form with $\theta=0.5$. Lastly, we set the fixed costs of employment costs to $\gamma=0.04$ to match labor force participation, as will be discussed further in Section 4.6.

income tax rates among U.S. households (see e.g., Romich, 2006; and Ellwood and Liebman, 2001). If these households are very close to a large jump in the marginal tax rate, the substitution effect coming from the phasing out of benefits will, all else equal, lower hours. The extent to which this affects aggregate labor supply depends critically on the mass of households near these high marginal-tax regions. Thus, the qualitative effects of the EITC on labor supply are ambiguous, even in a static setting. Saez (2010) contains a detailed analysis of "bunching" at the kink points of the tax systems.

${ }^{18}$ See Athreya (2008) for details in a similar environment. 
Table 1: Parameters

\begin{tabular}{|l|l|c|}
\hline Parameters & Description & Value \\
\hline$\beta$ & discount rate & 0.95 \\
\hline$J$ & working years & 48 \\
\hline$K$ & retirement years & 25 \\
\hline$j_{y}$ & years as single without children & 6 \\
\hline$j_{a}$ & years as single with children & 25 \\
\hline$x_{i}$ & probability of having 0, 1 and 2 children & $\{0.623,0.195,0.182\}$ \\
\hline$\alpha$ & coeff. of relative risk aversion & 3 \\
\hline $1-\theta$ & leisure share & 0.5 \\
\hline$\tau(\cdot)$ & marginal tax rate & discretized \\
\hline $\bar{c}$ & minimum consumption floor & $\$ 3,000$ per adult \\
\hline$\tau^{R}$ & minimal retirement transfers & 1.02 \\
\hline$R^{f}$ & risk free rate & 0.065 \\
\hline$\psi$ & transaction costs & 0.04 \\
\hline$\gamma$ & employment costs & 0.95 \\
\hline$\rho$ & persistence of wage shock & 0.021 \\
\hline$\sigma_{\eta}^{2}$ & variance of persistent shock & 0.018 \\
\hline$\sigma_{u}^{2}$ & variance of transitory shock & 0.25 \\
\hline$\sigma_{\eta_{1}}^{2}$ & variance of persistent shock at birth & 0 \\
\hline$\underline{x}$ & borrowing limit & \\
\hline
\end{tabular}

\subsection{Marginal Tax Rates and Transfers}

To calculate tax rates and liabilities for a very wide range of situations that households may find themselves in, we use data from TAXSIM version 9.0 from the NBER. We calculate the marginal income tax rates for single households with one and two children (i.e., dependent exemptions) for tax year 2008. For the baseline model economy, the marginal tax rates include the EITC and are reported in Figure 2.

We also need to parameterize the means-tested transfer function and retirement benefit. With respect to preferences for retirement wealth, we set $\alpha=3$. Turning first to the meanstested transfer function, $\tau_{w e l f}$, the interpretation is that households are eligible for a transfer, subject to the sum of the current income and wealth falling below a threshold deemed necessary by society. We denote this minimum consumption floor guaranteed by transfers under current U.S. policy as $\bar{c}$ and set $\bar{c}=\$ 3,000$ per adult equivalent. The dollar value of this income floor for household of median size is less than the inflation-adjusted value of Hubbard et al. (1995) of approximately $\$ 10,800$ in constant 1991 dollars per household annually, and closer to that of Scholz and Seshadri (2007) which includes welfare, food stamps and Medicaid. This allows the benchmark model to much better capture the observed asset accumulation of households in the lower percentiles of the wealth distribution. Transfers in retirement, $\tau^{R}$, guarantee the 
same household-level consumption floor as during working life: $\underline{\tau}^{R}=\$ 7,600 .^{19}$

\subsection{Wages}

The parameters of the stochastic process governing wages are set as follows: $\rho=0.95, \sigma_{u}^{2}=$ $0.018, \sigma_{\eta_{1}}^{2}=0.25, \sigma_{\eta}^{2}=0.021$. These values allow the model to match three important targets. First, the variances of the transitory shock and initial persistent shock allow the model to match the variance of log income among the youngest female-headed (working-age) households in the data. Second, the near-unit root in the persistent shock of $\rho=0.95$ generates the almost linear life-cycle growth of cross-sectional variance in log income documented in Storesletten et al. (2004). Third, the variance of the persistent shock beyond the youngest age captures the total increase in cross-sectional (log) income variance over the life-cycle, from approximately 0.28 among 21 year olds, to a pproximately 0.90 among new retirees. To parameterize the profile of the mean of log endowments over the life cycle, we use data on median earnings from the CPS (2000-2008) on unskilled U.S. females. Since endowments are log-normal, the mean of log endowments equals the logarithm of median endowments. Therefore, we take logs of the preceding estimates of median earnings, and generate age-specific profiles $\left\{\mu_{j}\right\}_{j=1}^{J}$.

\subsection{Asset Market}

We set the risk-free rate on savings to 2 percent, following Storesletten, Telmer, and Yaron (2004). In the benchmark economy, we assume that households cannot attain negative financial net worth, so that $\underline{x}=0$. We find that the results are robust to plausible relaxations in the borrowing constraint.

\subsection{Solution Method}

While our model is entirely standard in its specification of household productivity and asset markets, it is crucial for us to capture the variations in the marginal tax rate that arise not only from our specification of EITC, but also from the implicit taxes created by the asset-tested welfare programs that we allow for. Given the resulting fluctuations in the marginal tax rate that we displayed above, we require a solution for the household's decision problem that respects these variations. This rules out the use of standard smooth approximations to the marginal

\footnotetext{
${ }^{19}$ The probabilistic receipt of some classes of transfers (especially housing assistance) is part of what is being captured in this reduction. Notably, Hubbard et al. (1995) assign households the expected value of the transfer. However, this will overestimate the floor, as the value of the expectation will be strictly greater than the value of the lottery to the household. Lastly, the $\$ 10,800$ is arrived at by adjusting for inflation the $\$ 7,000$ income floor of Hubbard et al. (1995), which was measured in 1984 dollars, using the CPI "All Items" index. Moreover, less-than-100 percent utilization may also arise from various transactions costs, lowering the value of the transfer.
} 
tax rate schedule faced by the agents (e.g. the popular approximation of Gouveia and Strauss, 1994).

We proceed instead by allowing for a fine discretization for labor supply choices where individuals may choose labor supply to within 10 hours per year. To capture the variability in wages, we use the procedure of Tauchen (1986) to represent the stochastic components of the income process with a finite-state Markov chain. To ensure an accurate representation of wage risk, we use discrete grids that allow for 15 values for the persistent shock and 7 values for the transitory shock, respectively.

For each combination of age, realizations for the persistent and transitory components faced by a household, and labor supply level, we compute the exact tax liability, net of the EITC credit. Next, we compute the optimal level of consumption and savings for this given level of labor supply. Lastly, we select the labor supply level that maximizes the relevant value function, subject to optimal consumption and savings given this choice, and the budget constraint. Given decision rules for each age of life, we then simulate lifetime outcomes for approximately 2,500 different agents, and then use moments of the associated distribution of outcomes.

In this way, we obtain decision rules for consumption, savings, and labor supply from the oldest age to the youngest age via standard discrete-state space dynamic programming. ${ }^{20}$ To ensure robustness, we have experimented with grids even finer than those used in the benchmark but find that they yield essentially identical results, while the computational burden increases substantially due to the number of evaluations across possible labor supply levels (including zero hours) for each vector of the current state variables. We now turn to the fit of the baseline model, after which we present the results.

\subsection{The Fit of the Baseline Model}

We first compare the predictions of our benchmark calibration to data on EITC participation, household income and labor supply. The household-level data is from the 2008 Current Population Survey (CPS). As noted earlier, given our objective, we restrict the sample to single mothers between the ages of 25 and 44 with a high school degree or less. ${ }^{21}$ Households are classified into three types: single women with zero, one, or two children. All of the means reported represent weighted averages using the household weights supplied by the CPS. Recall that a model period represent one year so the means of the aggregates should be interpreted as annual averages. It is important to note that the CPS only reports estimated federal EITC and does not include state EITC's.

\footnotetext{
${ }^{20}$ The code is available from the authors on request.

${ }^{21}$ It is important to note that agents work for 48 years and then retire for 25 years in the model. However, the results we report from the model are for the relevant group of single mothers when they have children in the household, which is between the ages 25 and 44 .
} 
In Table 2, we report the central facts that we seek to match, and their model counterparts. In the calibration, we set employment costs $(\gamma)$ to match observed labor force participation rates of 78 and 77 percent for young, single mothers with one child and those with two children, respectively. Following Cogan (1981) and Eissa, Kleven and Kreiner (2008), we assume there are adjustment costs associated with entry into the labor market, and for single mothers these typically include the search for adequate child care. We find that employment costs of $\gamma=0.04$ are able to generate labor force participation rates of 78 percent and 75 percent, respectively. We then check to see how the model delivers in matching other facts, including EITC participation rates, income, and EITC amounts.

For simplicity, our model abstracts from any stigma, fixed costs, or informational asymmetries associated with receiving the EITC, conditional on qualification. Thus, in our model, those who qualify for the EITC receive it with probability one. Naturally, therefore, the model overstates EITC participation rates, defined as the percent of each household type that receives the EITC. As an empirical matter, our benchmark model performs sensibly; there is strong evidence that EITC take-up rates vary between 50 percent and 80 percent at the national level (Caputo, 2009; Urban-Brookings Tax Policy Center, 2010), which is in the range of our estimates.

We next compare mean household income for EITC recipients in the model and the data. Overall, the model is able to closely match mean household incomes for single mothers with one child, but it slightly overstates mean income for single mothers with two children $(\$ 19,187$ in the model, compared with $\$ 16,479$ in the data). This leads to the model overstating EITC levels (for those who receive the EITC), especially for young, unskilled single mothers with two children. This is because the model is overstating income levels for the poorest of these households. Given that the employment costs are fixed and do not vary with income, we cannot fully match the income distribution for EITC recipients. Higher income in the model allows these households to collect more EITC than what is reported in the data. Still, the relative levels of income and EITC across household types are close enough to the data to not warrant much concern.

Lastly, while we do not in any way target wealth holdings, the model has implications for these statistics as well. For those with nonnegative net worth (which is consistent with the benchmark model with a borrowing constraint of zero), young unskilled mothers with one child have on average $\$ 4,624$ in mean net worth, compared with $\$ 3,051$ with two children in 2007 SCF data. The model produces mean asset holdings of $\$ 12,844$ and $\$ 9,753$ for single mothers with one and two children, respectively.

Explicitly matching asset holdings (or net worth) in the data is problematic for the subgroup of the population of interest to us. Most notably, while the the Survey of Consumer Finances (SCF) has precise data on the balance sheet of those whom it observes, it undersamples poor 
households. This implies that these data contain very few unskilled, single mothers of any given age. For example, in the $2007 \mathrm{SCF}$, there are only 255 unskilled, young single mothers across all ages.

Table 2: Model versus Data

\begin{tabular}{|l|l|c|c|}
\hline & & $\begin{array}{c}\text { Single, } \\
\text { 1 Child }\end{array}$ & $\begin{array}{c}\text { Single, } \\
\text { 2 Children }\end{array}$ \\
\hline Targeted moments: & & & \\
\hline Labor force participation & Model & 0.776 & 0.753 \\
\hline & Data & 0.783 & 0.767 \\
\hline Non-targeted moments: & & & \\
\hline EITC participation rate & Model & 0.698 & 0.709 \\
\hline & Data & 0.589 & 0.625 \\
\hline Household Income, EITC recipients & Model & $\$ 15,386$ & $\$ 19,187$ \\
\hline & Data & $\$ 15,766$ & $\$ 16,479$ \\
\hline Amount of EITC & Model & $\$ 2,581$ & $\$ 4,286$ \\
\hline & Data & $\$ 2,026$ & $\$ 2,820$ \\
\hline Asset holdings & Model & $\$ 12,844$ & $\$ 9,753$ \\
\hline & Data & $\$ 4,624$ & $\$ 3,051$ \\
\hline
\end{tabular}

Notes: Data are from 2008 CPS, represent weighted averages, and are in 2008 dollars.

\section{Results}

We now provide results, beginning with the impact of the EITC on aggregate quantities for consumption, leisure and wealth. We then analyze the effects of the EITC on household-level decisions. With these results in hand, we will turn to the main question of the insurance role of the EITC against productivity risk and demographic uncertainty.

We remind the reader that our approach is to compare our baseline model (with the EITC based on 2008) with those of a counterfactual experiment in which the EITC is completely eliminated. Also, it is important to stress again that ours is a steady state analysis: We compare outcomes from the benchmark economy (featuring the EITC) to one where the EITC has been eliminated for long enough that outcomes reflect the decisions of a cohort whose members have used decision rules that reflect the absence of EITC for their entire lives. This is a clean counterfactual to locate the long-run effects of the EITC that does not require adjustment for transition, cohort, or time effects. It is therefore complementary to the large body of empirical work aimed at disentangling the effects of EITC in real-time data. When we change the EITC, we hold fixed all other parameters. Thus, the only change is that the income tax schedule will not include the effects of the EITC (as plotted in Figure 2). Marginal income taxes still vary (based on the 2008 federal income tax code) with the number of dependent children, but do 
not include any effects directly due to the structure of the EITC.

\subsection{The EITC and Aggregate Outcomes}

We first analyze the more traditional measures of the effectiveness of the EITC - those having to do with aggregate consumption, wealth, and labor supply. Table 3 presents the aggregate implications of the EITC by comparing moments of the distributions of consumption and leisure, as well as the rates of labor force participation, arising from the baseline model to those coming from the elimination of the EITC. We also present results on the effect of the EITC on asset holdings and consumption. Recall that a model period represents one year so the means of the aggregates should be interpreted as annual averages.

First, we find that the EITC has significant effects on labor force participation (as reported in Table 3). The model implies that, all else held equal, in a world without any EITC, labor force participation rates would be significantly lower among its target population in the long run. In fact, there would be between a 17 and 25 percentage point reduction in labor force participation rates among young, unskilled single mothers.

Much of the empirical literature has documented sizable, positive effects from the EITC on the extensive margin of labor supply (Eissa and Leibman, 1996; Meyer, 2001; Grogger, 2004). For example, Meyer and Rosenbaum (2001) estimate a 7-10 percentage point increase in labor force participation between 1990 and 1996. Clearly, those studies find smaller effects because they evaluate smaller regime changes in the EITC (such as variation in state EITCs or smaller changes in the federal EITC over time). Recall that in our analysis, single mothers are deciding whether or not to enter the labor force by comparing a tax credit of 40 percent (for those with two children) compared with a tax rate of 0 percent with no EITC. Thus, the high phase-in rates of the EITC encourage many single mothers to enter the labor force, and especially for those who are closest to the borrowing constraint.

Given that the EITC has existed since 1975 but that it was not significant in size and scope until the early 1990s, our model suggests that the EITC could have been an important determinant of the relatively high labor force participation rates we have observed for single mothers in the United States since then. Of course, in the observed time-series, all else is not being held equal, such as the generosity of traditional welfare and more importantly, the strengthening U.S. economy (as analyzed in Chan, 2013). However, our model allows us to isolate the role of the EITC. 
Table 3: EITC vs No EITC

\begin{tabular}{|l|l|c|c|}
\hline Variable & Model & $\begin{array}{c}\text { Single, } \\
\text { 1 Child }\end{array}$ & $\begin{array}{c}\text { Single, } \\
\text { 2 Children }\end{array}$ \\
\hline Labor force participation & EITC & 0.776 & 0.753 \\
\hline & No EITC & 0.600 & 0.497 \\
\hline Hours worked (for those who work) & EITC & 0.461 & 0.446 \\
\hline & No EITC & 0.519 & 0.506 \\
\hline Assets & EITC & $\$ 12,844$ & $\$ 9,753$ \\
\hline & No EITC & $\$ 15,251$ & $\$ 11,612$ \\
\hline Consumption & EITC & $\$ 11,101$ & $\$ 9,702$ \\
\hline & No EITC & $\$ 9,961$ & $\$ 7,862$ \\
\hline
\end{tabular}

Interestingly, the effects on the intensive margin of labor supply are quite different. As seen in Table 3, the EITC encourages single mothers in the labor force to work fewer hours per year. Notice that annual hours worked fall by approximately 10 percent for single mothers with one child, from 0.519 to 0.461 hours on average (hours are normalized to be between 0 and 1 ). A similar reduction occurs for single mothers with two children. For these women, the marginal tax rates they face are quite high with the EITC, as shown in Figure 2. Once their income reaches a threshold (of approximately $\$ 20,000$ ), marginal tax rates go from approximately 10 percent without the EITC to approximately 31 percent as they are being phased out of the EITC. These high marginal tax rates discourage work. Both substitution and income effects work in concert to discourage work: The substitution effect influences households to substitute leisure for hours worked while the income effect, given the substantial size of the EITC transfer, can reduce hours worked further. Since a majority of EITC recipient households fall in the flat or phase-out region (Hotz and Scholz, 2003), the overall effects of the EITC on hours worked should be negative, ceteris paribus, just as we find. In addition, more unskilled single mothers are entering the labor force with the EITC so it is possible that some single mothers could be working the same or even more with the EITC while others are working less. We will decompose these effects in our discussion below.

Empirical work has produced a range of findings with respect to the effects of the EITC at the intensive margin. For example, Eissa and Liebman (1996) find no effects for unskilled single mothers. Others suggest that the effects on annual hours for single women may be negative (Dickert, Houser, and Scholz, 1995). However, getting clean estimates for the intensive margin is difficult because of the selection and endogeneity biases present in the nonexperimental data (Eissa and Hoynes, 2006). Our approach allows us to circumvent these difficulties.

We turn next to the effect of the EITC on household asset accumulation. ${ }^{22}$ Recall first

\footnotetext{
${ }^{22}$ Notice also that the existence of a welfare system in the model not only provides insurance, but due to its means-tested nature, penalizes savings (just as analyzed in the seminal work of Hubbard et al., 1995). Since a welfare system is present and identical in both economies we consider, however, it should not directly alter the
} 
that the EITC is more precisely structured to deliver insurance than a simple rainy-day fund that households might accumulate. Hence, it may entice households to save less, and the more effective it is at providing insurance, the larger this drop ought to be. However, there is a countervailing force: The EITC makes average effective wages for the household flatter over the life cycle. It does this because younger households have lower average wages than older ones. As a result, younger households on average will qualify for larger transfers than older ones (for any given labor supply level). This makes purely intertemporal smoothing less relevant than it would be without the EITC. In other words, without the EITC, younger households can expect to be substantially better off in the future than in the present. As a result, these households may choose not to save as much, ceteris paribus. The EITC flattens life-cycle earnings and encourages saving for later in life, especially retirement.

Table 3 shows that asset holdings are substantially lower in the presence of the EITC. Given the argument above, this is strong evidence that it serves as an important form of insurance for households. Moreover, because the EITC allows households to smooth consumption by saving less and reducing their precautionary savings, it leads to higher mean consumption. In fact, for single mothers with two children, savings fall by 16 percent with the EITC but mean consumption increases by approximately 23 percent. (For single mothers with one child, savings falls by 16 percent and consumption increases by 11 percent.) Thus, the EITC allows households to smooth and increase consumption simultaneously. While the size of the reduction in assets is clear evidence of the insurance role played by the EITC, it is indirect evidence. How does the EITC alter consumption variability? We will address this further below, but first lay out the behavior of aggregate-level outcomes. ${ }^{23,24}$

At the extensive margin, the EITC unambiguously encourages (ceteris paribus) work effort. However, it encourages work effort more for those experiencing low productivity. As a result, raw hours of work might rise by more than effective hours. More generally, the effect of the EITC is to shift the entire distribution of "who works." To better understand this, we next plot the cumulative distribution function (cdf) for effective labor hours and consumption for both types of households across various efficiency levels. We define efficiency as the ratio of the wage relative to the maximum wage for that household type. Thus, the most efficient agent is the agent who received the highest persistent and transitory shock, while agents with efficiency levels close to zero face the most adverse productivity shocks. As you can see in Figure 3, the EITC spurs more inefficient people to work. Effective labor hours are higher for those with bad productivity shocks and this holds for both types of households. In fact, the EITC has the

role played by the EITC.

${ }^{23}$ This result is also not a feature of the non-negativity bound on net worth imposed in the benchmark model. We considered a case when the borrowing constraint was relaxed so that households could borrow up to 10 percent of their income, and we find the results unchanged.

${ }^{24}$ For brevity, the results are not reported in a table but are available from the authors. 
largest effect on encouraging work for single mothers with two children: The cdf is higher at each efficiency level. For households with moderate and high productivity shocks, the EITC is not affecting their labor supply decision.

Figure 3: CDF of Effective Hours: EITC vs No EITC
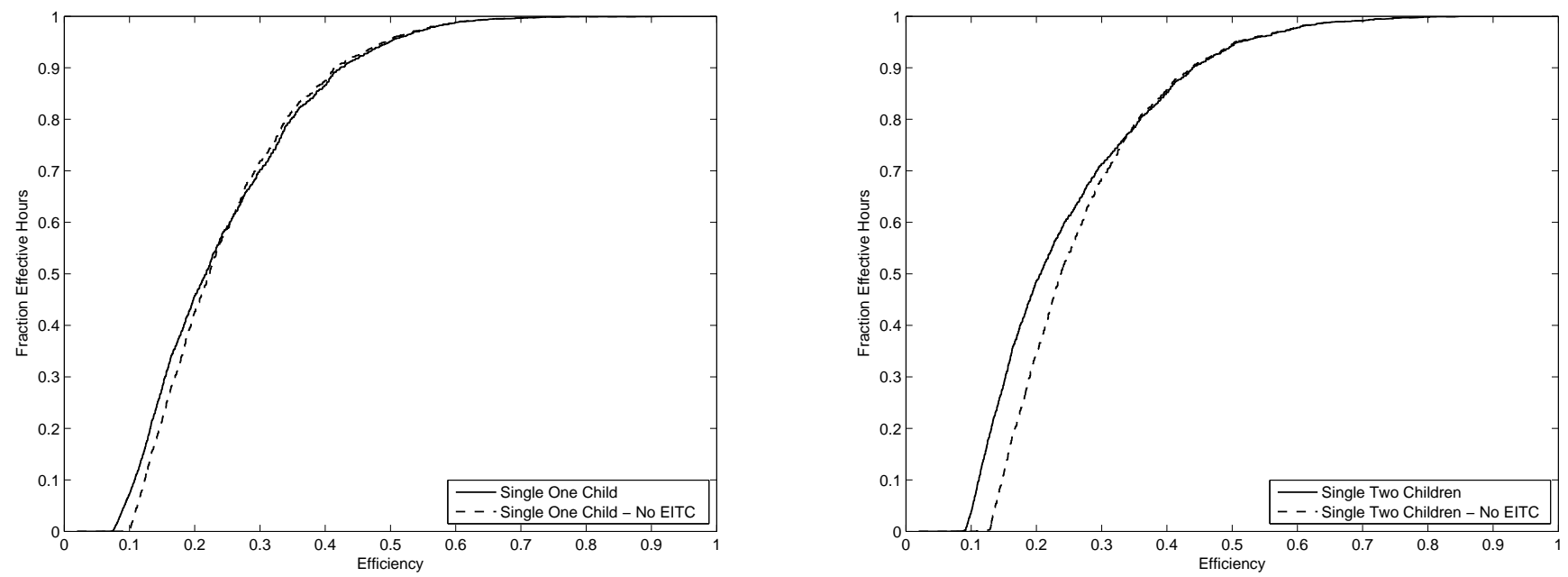

Figure 4 indicates a similar pattern for consumption. The distribution under the EITC is higher than that without the EITC at every efficiency level, except for perhaps the very lowest efficiency households where the two overlap. This implies that the EITC encourages higher consumption for even the most inefficient households. Once again, the effects of the EITC on consumption become minimal for households who experience good productivity shocks, indicating that the EITC is most important for households who receive bad draws in the income distribution. 
Figure 4: CDF of Consumption: EITC vs No EITC
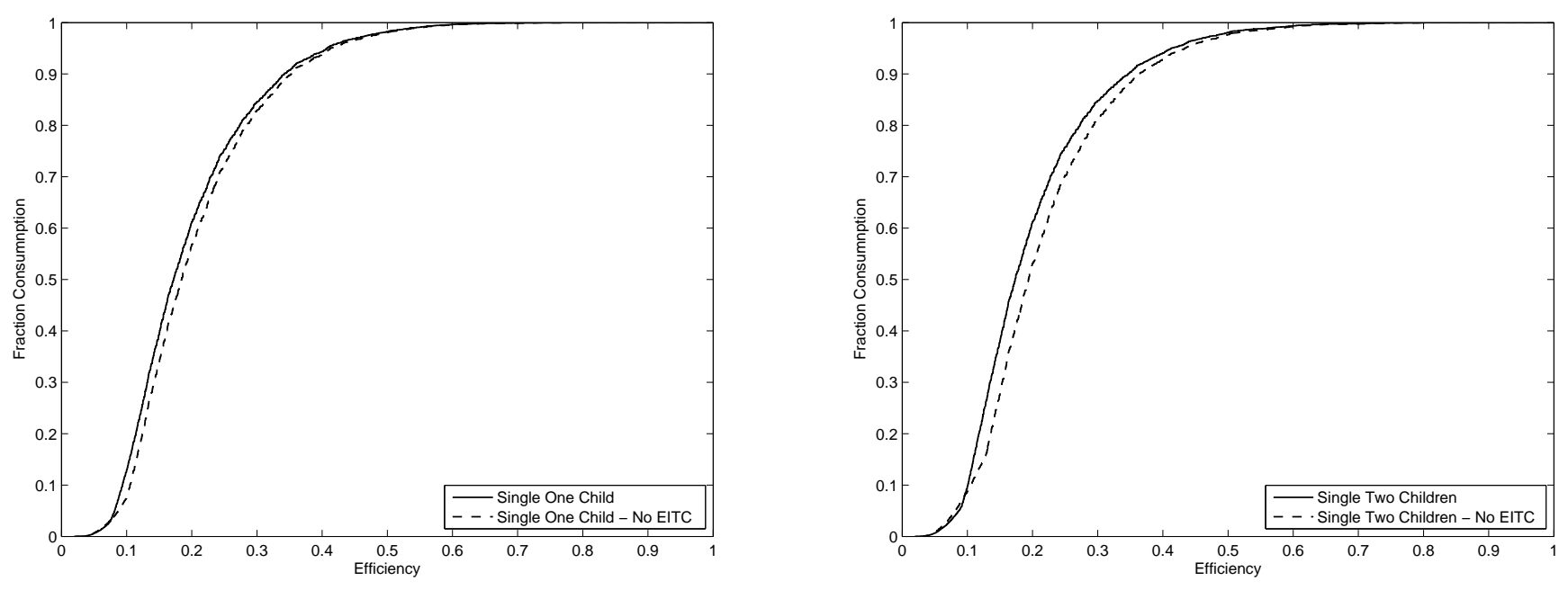

The fact that, as seen above, the EITC has differential effects on labor supply for various levels of productivity makes it useful to decompose the change in effective hours into components at the intensive and extensive margins. After all, total effective hours depends on the measure of any given productivity level and the hours of those who work. In Figure 5, we plot labor hours for each quartile of worker efficiency. For brevity, we present results for single women with two children only, noting the results are very similar for those with one child (with the slight exception of those in the second productivity quartile, who work less than their one-child counterparts). In the left-hand panel of Figure 5, we plot average hours worked, which combines both those who work positive hours and those who do not. This contrasts with the right-hand side, which displays average hours worked for only those single women with two children who work positive hours.

Comparing these two panels for those in the bottom quartile of productivity shows clearly that for the least productive, the EITC is very important in encouraging labor supply. A quick summary is as follows. For mothers with below-median productivity, labor supply is low overall, but it rises sharply in the presence of the EITC. This is true irrespective of whether labor supply is measured in terms of either unconditional labor supply or hours conditional on working. Conversely, for those with above-median productivity, irrespective of the EITC, labor supply conditional on working does not vary much. And with respect to the EITC, we see that for this group, labor hours falls slightly with its introduction. This fall occurs entirely at the intensive margin, as participation rises (slightly) with the introduction of the EITC for the upper two quartiles of productivity (see Figure 6).

The varied effects of the EITC are striking. For instance, among those with the lowest productivity, we find that the absence of the EITC leads them to work almost zero hours 
overall, and only about one-sixth of available time for those who work positive hours. For these households, the incentives to work are severely limited by the worker's very low wage, as well as the eligibility of this group for the income floor of the welfare system. Once EITC is introduced, however, Figure 6 shows that a sizeable proportion enter the labor force (roughly half of all workers in this group) and supply roughly half of their time endowment to the labor market. Overall labor supply, though, is still low in comparison to other productivity groups.

The second quartile of productivity exhibits similar behavior in terms of overall hours being low, but there are two differences. First, as seen in Figure 6, in the no EITC case, the fraction of second-quartile households who work positive hours is substantially higher for their lowest quartile counterparts. Conditional on working positive hours, second-quartile households work many more hours. For both of these reasons, the overall labor supply of the second quartile is quite a bit larger than the first quartile. Second, we see clearly that the second quartile group is the one for whom the EITC is most important: Both hours conditional on working positive hours, and participation rates, are far higher with the EITC than without it. Workers in the second quartile of productivity are in a "sweet spot": They are productive enough to choose to work, but not so productive that they face the EITC phase-out for a wide range of effort levels. For those with above-median productivity, the effects are far less dramatic, as the EITC's phase-out region becomes more relevant and results in high taxes on work effort that appear to almost completely nullify the increase in average wages coming from the EITC.

Figure 5: Labor Hours by Efficiency Level for Single Mothers with Two Children
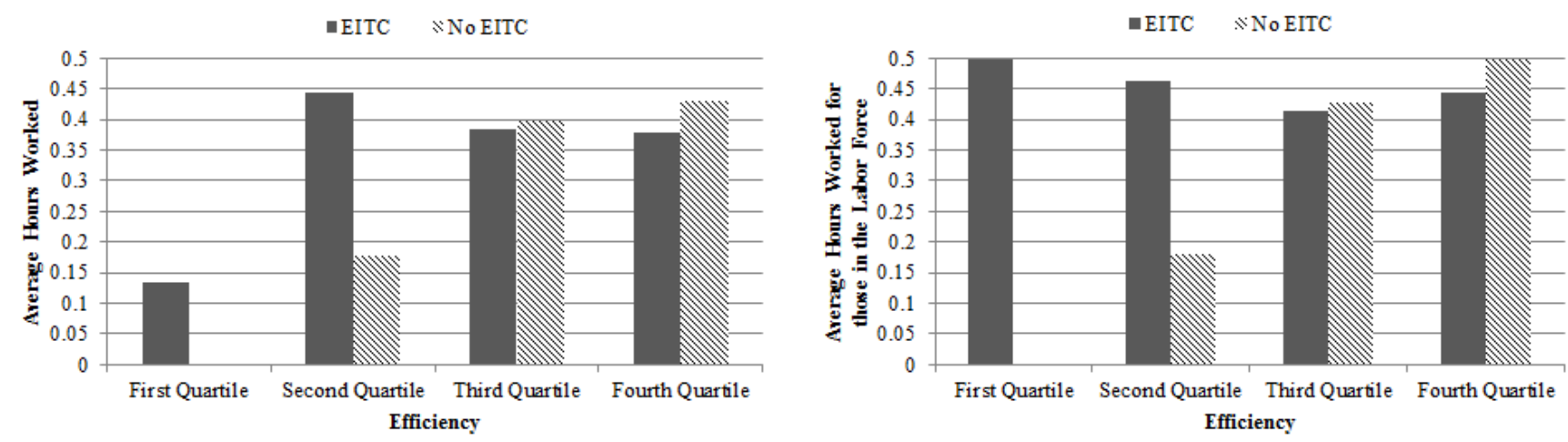
Figure 6: Labor Force Participation by Efficiency Level for Single Mothers with One and Two Children
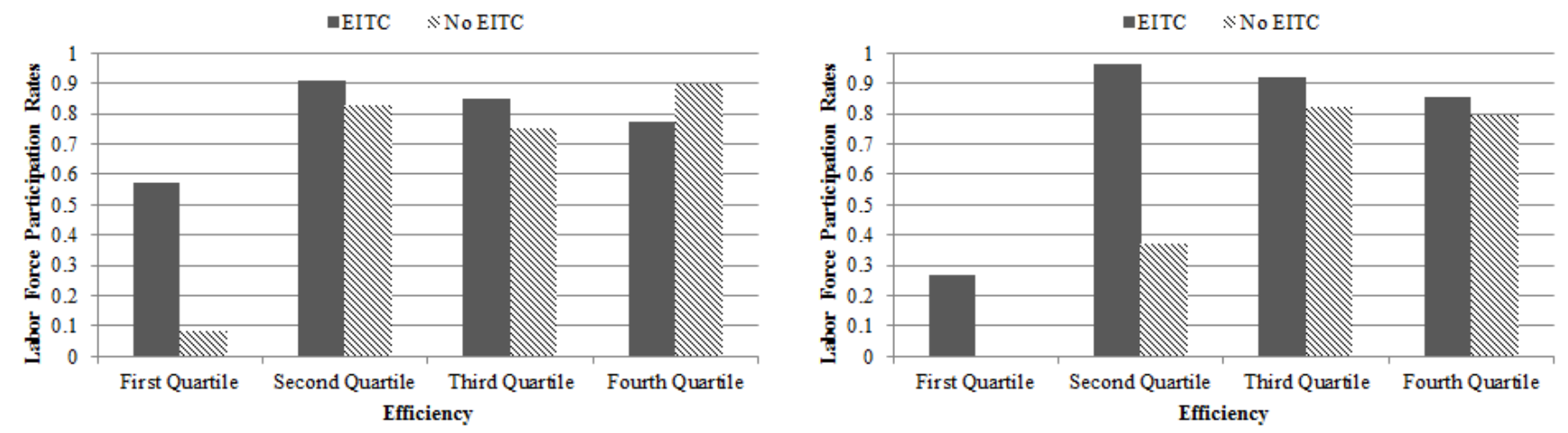

We summarize our findings thus far as follows. The EITC has important aggregate effects for young unskilled single mothers with children: Labor force participation increases but hours worked decrease. The EITC leads single mothers to save much less but still consume more. At the same time, the EITC disproportionately increases the labor supply of the least productive workers, and leaves the work effort of the most productive unchanged. From a social-planning perspective, we note that matters are less clear: Our analysis suggests that the EITC clearly increases the labor supply of the least productive, while leisure is valued by all households. It may therefore be the case that if household-level productivity were more directly observable, far better insurance might be made available. In particular, insurance that avoids incentivizing lowproductivity households to work, and incurs disutility and the deadweight losses of commuting, etc., may be preferable.We turn next to the effects of the EITC on life-cycle statistics.

\subsubsection{Asset Holdings and Labor Supply Decisions over the Life Cycle}

At the individual level, the EITC has important effects on decisions, especially over the life cycle. Recall that only young (age 25-44) single mothers are eligible to receive EITC in the model. This age range represents the age when women are most likely to have dependents in the household. The two panels of Figure 7 plot mean asset holding and labor hours over this portion of the life cycle.

In Figure 7, we plot average labor hours by age for both types of households with and without the EITC. This sample represents only those households who work and hence qualify for the EITC. We see that the EITC causes mean labor hours to be substantially lower at each age as compared to the no EITC case. In addition, mean labor hours are higher for single mothers with one child compared to those with two children, and this is true with or without the EITC. On average, hours worked are relatively constant over the life cycle. 
All, however, is not being held fixed, as asset holdings vary systematically under the two policy regimes. This is seen in Figure 7 where we plot asset holdings over the life cycle with and without the EITC. The insurance role of the EITC is seen most clearly here in the dramatic reduction in asset holdings, reflecting reduced precautionary motives to save. Notice that the gap in mean asset holdings shrinks as household heads approach the age at which children leave the home. This is due to the EITCbecoming sharply less generous for those with no children, making the two regimes very similar to each other. In fact, without the EITC, asset holdings begin to fall as households get older and exhibit the typical life-cycle pattern. However, when they have access to the EITC, asset holdings continue to increase with age. Thus, the reduction in asset holdings that we observe in the aggregate hides the fact that households that receive the EITC save less when they are younger as compared with the no EITC case, but they save more as they get older. In this sense, the EITC enables more savings later in life.

While assets converge over the life cycle, we know that wages are higher at all ages due to the nature of the EITC. This is why consumption in the presence of EITC must be higher as seen in Table 3. Given Cobb-Douglas preferences over consumption and leisure within each period, households seek to allocate a constant share of total resources to the purchase of each. All else equal, increased levels of consumption will be accompanied by households spending more of their "potential income" - that is, income if all time were supplied - on leisure as well. As a result, this leads to lower mean labor effort throughout the portion of the life cycle during which children are present. As children near the age where they depart the household, assets return to the levels seen without the EITC and surpass them. In essence, households understand the limitation on their eligibility for generous EITC, even if nominal EITC benefits are understood to remain available after children leave the household, and therefore prepare via asset accumulation. 
Figure 7: Assets and Labor Hours over the Life Cycle: EITC vs No EITC
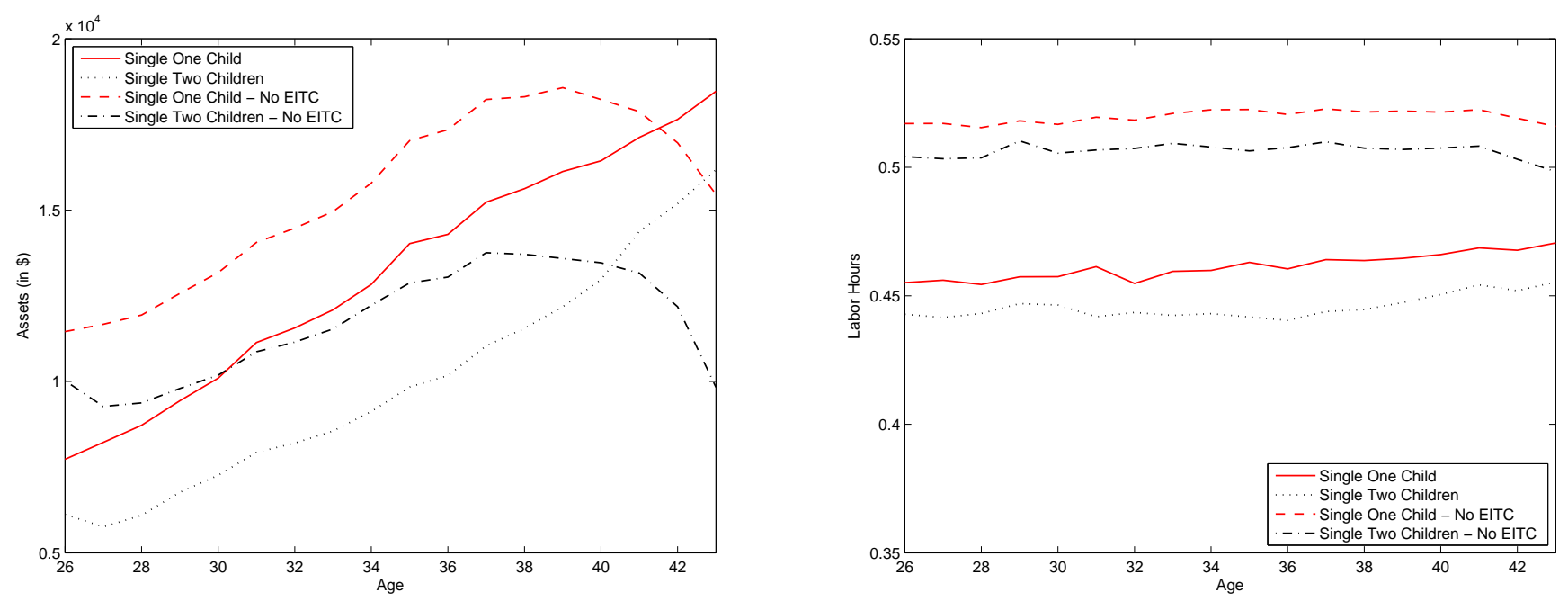

\subsection{The EITC as Insurance}

Having assessed the effect of the EITC on aggregates and obtained a sense of the mechanisms at work, we turn now to the main question of interest: How much insurance does the EITC provide?

A natural way to measure the insurance role of the EITC is through the distribution of lifetime consumption across households. Figure 8 displays selected percentiles of the distribution of (the net-present value of) lifetime consumption. That is, at each age, the figure collects consumption levels for the set of people whose lifetime consumption places them in the given percentile bin. We see immediately that the introduction of the EITC has strong positive effects on lifetime consumption levels for the lowest percentiles. Moreover, the effect of the EITC on lifetime consumption is stronger for the lowest percentiles than it is at the median. While not shown for brevity, higher percentiles show even smaller changes as the EITC phases out for such households.

Further reducing these data into simple ratios of percentiles of the consumption distribution, averaged across the entire lifecycle, is instructive. Table 4 shows clearly that the EITC lowers the ratio of the mean consumption (over the life cycle) of the 90th percentile to the mean of the 10th percentile the most (e.g., "Average 90-10 ratio" in Table 4), and has strong compressing effects on the "50-10" and "25-10" ratios as well. In sum, when measured by metrics related to the cross-sectional variability of consumption, the EITC appears to provide significant lifetime consumption insurance. 
Figure 8: Net Present Value of Lifetime Consumption: EITC vs No EITC

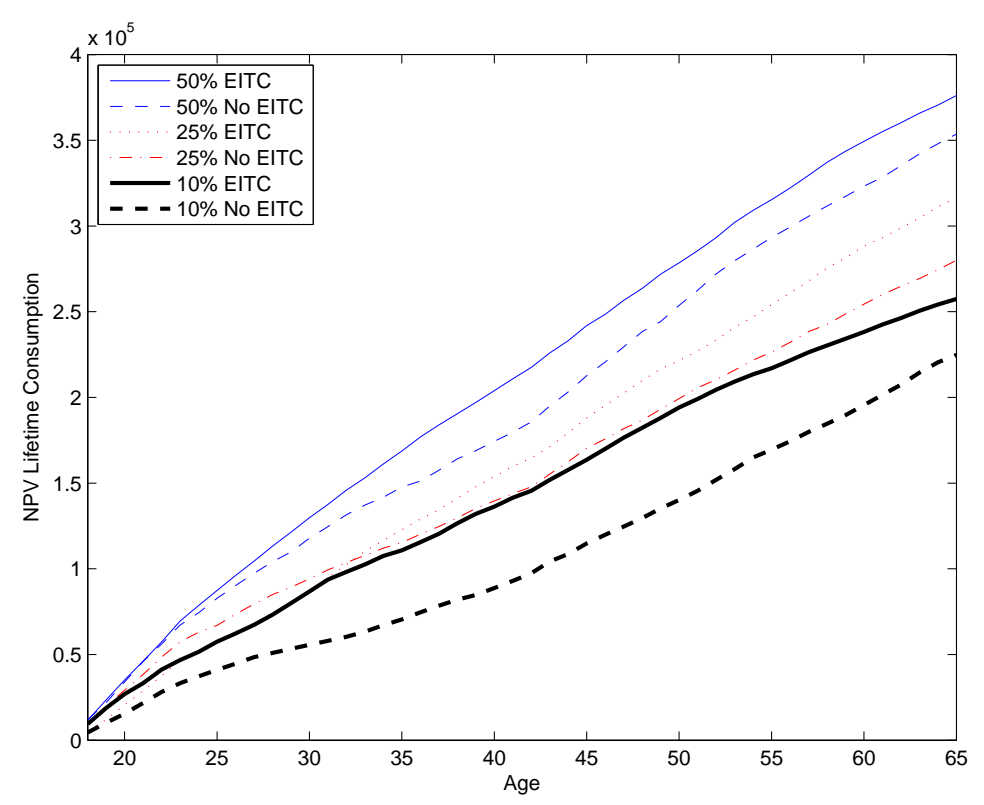

Table 4: Mean Lifetime Consumption Ratios: EITC vs No EITC

\begin{tabular}{|l|l|c|}
\hline Variable & Model & $\begin{array}{c}\text { Consumption } \\
\text { ratio }\end{array}$ \\
\hline Average 90-10 ratio & EITC & 1.930 \\
\hline & No EITC & 3.000 \\
\hline Average 50-10 ratio & EITC & 1.464 \\
\hline & No EITC & 1.916 \\
\hline Average 25-10 ratio & EITC & 1.083 \\
\hline & No EITC & 1.539 \\
\hline
\end{tabular}

Having shown that the EITC compresses the distribution of consumption, we now turn to more disaggregated measures focused on each of the two specific risks that the EITC's structure protects against: productivity risk and demographic risk. We proceed by measuring the EITC's ability to lower volatility in consumption and leisure. Table 5 shows that the EITC reduces consumption volatility for both types of households substantially. It presents the standard deviation and coefficient of variation (CV) (as well as the mean) of consumption and leisure for each demographic type. The coefficient of variation is the ratio of the standard deviation to the mean of each variable and is useful because it is unit-free. While we will not stress welfare in our calculations, we note that the CV has the added benefit that to a first approximation, the amount that an individual would be willing to pay to eliminate a risk is proportional to the square of CV (see Newbery, 1989). 
We first evaluate the EITC's power to protect households against reductions in productivity, and then move to the case of demographic risk.

\subsubsection{The EITC as Productivity Insurance}

Table 4 gathers the relevant findings and, in a clear sense, represents the punchline of the paper: The EITC substantially lowers consumption variability for single mothers. As seen in the table, the EITC leads single mothers with one child to experience a 12 percentage point reduction in consumption volatility as measured by the CV. Moreover, the reduction in consumption volatility is largest for those who have experienced the most substantial shock to household demographics: Mothers who find themselves sole providers for two children. These mothers experience a 17 percentage point reduction in consumption variation. The structure of the EITC is clearly playing a role here: Single parents with two children obtain the largest transfers available through the EITC. In sum, the EITC is an unambiguously important insurance mechanism for single mothers.

Table 5 also reports the effects on leisure for those households who are in the labor force. We find that both the mean and standard deviation of leisure is higher with the EITC than without it. The net effect is that the coefficient of variation for leisure is higher with the EITC: The increase in the standard deviation is larger than the increase in its mean. The variability of the leisure distribution is precisely the mechanism described earlier, and brought out in Domeij and Floden (2001) and Pijoan-Mas (2006). As an aside, the EITC is slightly increasing the dispersion in the distribution of leisure among those households that work. ${ }^{25}$ That is, the single mothers in the model begin life with zero net financial wealth at age 18 and have little time to build up a rainy-day fund by the time the number of dependent children is determined. As a result, these households (up to tax considerations) supply labor relatively inelastically, leading to low variability in leisure and labor supply.

For assets, the EITC encourages households to save less, and consequently we observe lower mean asset holdings in the EITC regime. While the standard deviation of asset holdings also fall, it is not enough to offset the large decrease in mean assets, so that the coefficient of variation for assets is higher with the EITC. In fact, the standard deviation of asset holdings in the model is twice as large as the mean in most cases. Thus, the distributions of asset holdings and leisure become more dispersed in a world with the EITC, while the distribution of consumption becomes more equal.

\footnotetext{
${ }^{25}$ Note that if we include all households in these calculations (including those who do not work), the distribution of leisure is less disperse.
} 
Table 5: Coefficients of Variation: EITC vs No EITC

\begin{tabular}{|l|l|lll|lcc|}
\hline Variable & Model & \multicolumn{3}{|c|}{ Single, 1 Child } & \multicolumn{4}{c|}{ Single, 2 Children } \\
& & Mean & SD & CV & Mean & SD & CV \\
\hline Consumption & EITC & 11,099 & 4,169 & 0.376 & 9,701 & 3,820 & 0.394 \\
\hline & No EITC & 9,960 & 4,954 & 0.497 & 7,860 & 4,496 & 0.572 \\
\hline Leisure (for those who work) & EITC & 0.539 & 0.047 & 0.088 & 0.554 & 0.050 & 0.090 \\
\hline & No EITC & 0.481 & 0.038 & 0.078 & 0.494 & 0.038 & 0.078 \\
\hline Assets & EITC & 12,229 & 25,008 & 2.045 & 9,230 & 21,772 & 2.359 \\
\hline & No EITC & 15,072 & 28,910 & 1.918 & 11,720 & 26,386 & 2.251 \\
\hline
\end{tabular}

We have focused thus far on consumption variability and noted that the EITC sharply reduces it while leaving variability in leisure relatively stable. However, households care in a given period about the combination of consumption and leisure. To study the extent to which this object is smoother, we calculate the amount of insurance that the EITC provides for the combination of consumption and leisure as dictated by our Cobb-Douglas utility function. In Table 5, notice that mean consumption and leisure increase with the EITC. We define a composite good as $\frac{c_{j}}{E S_{j}} l_{j}^{1-\theta}$ where $\frac{c_{j}}{E S_{j}}$ is effective consumption, $l_{j}$ is leisure, at age $j$, and $1-\theta$ is the elasticity of labor supply (which we set as $\theta=0.5$ ). In Table 6 , we report the mean, standard deviation and coefficient of variation for the composite good. The EITC has differing effects on the two household types, but the effects are small overall. For single mothers with one child, the EITC raises the mean and lowers the standard deviation, leading to a reduction in the CV. For single mothers with two children, the EITC again raises the mean by raising the standard deviation enough to cause a small increase in the CV (which is being driven by the standard deviation of leisure). Overall, the net effect on the coefficient of variation is small in both cases.

\begin{tabular}{|c|c|c|c|c|c|c|c|}
\hline \multirow[t]{2}{*}{ Variable } & \multirow[t]{2}{*}{ Model } & \multicolumn{3}{|c|}{ Single, 1 Child } & \multicolumn{3}{|c|}{ Single, 2 Children } \\
\hline & & Mean & $\mathrm{SD}$ & $\mathrm{CV}$ & Mean & $\mathrm{SD}$ & $\mathrm{CV}$ \\
\hline Composite good & EITC & 80.08 & 8.19 & 0.102 & 78.45 & 7.84 & 0.099 \\
\hline & No EITC & 76.78 & 8.42 & 0.110 & 73.92 & 7.13 & 0.096 \\
\hline
\end{tabular}

We now turn to more disaggregated measures of consumption insurance coming from the EITC. We proceed by looking at households who have experienced negative productivity shocks in the current period and compare the coefficients of variation of consumption, leisure, assets, and indirect utility. Specifically, we analyze the response of households who experience "low" shocks, where "low" is defined as a shock that is below the median shock (either persistent or 
transitory shock). Note that we measure the means in the period that the shock occurred. Table 7 reports the coefficients of variation for each household type with low persistent and low transitory shocks. ${ }^{26}$

Importantly, the EITC sharply lowers the CV for consumption for households who have just experienced a bad productivity shock. The model suggests that without the EITC, the households most susceptible to relatively low income shocks would experience much more consumption volatility if the EITC did not exist. This is true for both low persistent shocks and low transitory shocks. This is especially relevant given that single mothers have very few other sources of insurance against bad income shocks. Thus, the EITC is especially important for single mothers who experience lots of volatility in income and are in the most dire of economic situations. Among both types of families with dependents, households with a poor realization of the persistent shock also have more dispersed wealth positions (as measured by the CV of assets) in the absence of the EITC. A low persistent shock leads to a much more substantial reduction in wealth than a low transitory shock. A useful point to note is that in the absence of the EITC, the variability in consumption is substantially higher among those hit by a poor realization of the persistent shock than among those with a negative realization of a transitory shock. In the absence of EITC, this is natural, as persistent shocks have much larger lifetime implications than do transitory shocks of similar current magnitude. Once EITC is introduced, however, matters are different. Persistent shocks, despite their greater severity, have essentially no differential effect (relative to transitory shocks). Intuitively, this is because the EITC lessens the importance of the distinction, from the household's perspective, between transitory and persistent income risk. As noted at the outset, it is because the EITC boosts wages no matter the reason for the value they take in any given period, and indefinitely at that. This clearly showcases that the EITC's structure makes it a priori superior to the self-insurance households are able to muster in its absence. Finally, and as before, volatility in leisure is minimal.

Table 7: Coefficients of Variation: Households with Low Productivity Shocks

\begin{tabular}{|l|l|cc|cc|}
\hline Variable & Model & \multicolumn{2}{|c|}{$\begin{array}{c}\text { Single, 1 Child } \\
\text { Low pers }\end{array}$} & \multicolumn{2}{c|}{ Low trans } \\
& & Low pers & Low trans \\
\hline Consumption & EITC & 0.368 & 0.368 & 0.480 & 0.423 \\
\hline & No EITC & 0.537 & 0.498 & 0.500 & 0.574 \\
\hline Leisure & EITC & 0.046 & 0.053 & 0.052 & 0.083 \\
\hline (for those who work) & No EITC & 0.041 & 0.051 & 0.036 & 0.050 \\
\hline Assets & EITC & 2.491 & 2.100 & 3.084 & 2.404 \\
\hline & No EITC & 3.502 & 1.960 & 6.821 & 2.293 \\
\hline
\end{tabular}

Note: 'pers' represents persistent shocks; 'trans' represents transitory shocks; 'low' represents below the median.

\footnotetext{
${ }^{26}$ The means and standard deviations are available from the authors.
} 
Table 8: Coefficients of Variation Next Period: Households with Low Productivity Shocks

\begin{tabular}{|l|l|cc|cc|}
\hline Variable & Model & \multicolumn{2}{|c|}{$\begin{array}{c}\text { Single, 1 Child } \\
\text { Low pers }\end{array}$} & \multicolumn{2}{c|}{ Low trans } \\
& & Low pers & Low trans \\
\hline Consumption next period & EITC & 0.372 & 0.379 & 0.477 & 0.415 \\
\hline & No EITC & 0.551 & 0.495 & 0.622 & 0.591 \\
\hline Leisure next period & EITC & 0.050 & 0.094 & 0.063 & 0.099 \\
\hline & No EITC & 0.045 & 0.079 & 0.043 & 0.081 \\
\hline
\end{tabular}

Note: 'pers' represents persistent shocks; 'trans' represents transitory shocks; 'low' represents below the median.

Another way to gauge the insurance provision of the EITC is to ask about the variability of consumption expected to occur one period after they have experienced a temporary negative shock to wages. Table 7 collects the results and demonstrates that the EITC inoculates households against variability in near-term future consumption similar to how it mutes variability in contemporaneous consumption. This is evidence again that EITC works as an insurance scheme in a manner superior to that available through self-insurance. In particular, we see that the reduction in consumption variability one period after the shock is very similar regardless of whether the household was hit by a transitory or by a persistent shock. By contrast, and as before, we see that in the absence of the EITC, variability in consumption is substantially higher among those hit by a poor realization of the persistent shock than among those with a negative realization of a transitory shock.

\subsubsection{The EITC as Demographic Insurance}

We turn now to the role played by the EITC in insuring another major risk for targeted households, namely demographic risk. To do this, we depart from using the CV of consumption in favor of a simpler alternative. We consider the extent to which the EITC modifies the average consumption and wealth of households who experience each of the three possible demographic transitions: zero children, one child, or two children.

Table 9 presents the results. For those who do not face the care of any dependent children, the changes are trivial, with a gain of $\$ 2$ in the presence of the EITC and a loss of $\$ 120$ without the EITC. For the two other groups who experience transitions that end with the presence of dependents, matters are much different in that the EITC clearly shelters consumption. The size of the consumption reduction created by the arrival of dependents is large overall. For households who go from having no dependents to one dependent, the EITC reduces their consumption loss by $\$ 1,200$. Moreover, for households who end up with two children, the EITC protects them even more in that it reduces their consumption loss by $\$ 1,900$. It is important to note that the insurance value of the EITC would be even higher for households with two or more children if we were to include them. 
A similar story holds for asset holdings. In particular, we know from previous discussion that average asset holdings are higher in the absence of the EITC, despite lower average resources that households face when the EITC is eliminated. The change in assets is minor for those whose transition into adulthood generates zero dependents. But for those who have children, we see that the presence of the EITC strongly reduces the dissaving needed to keep consumption smooth. In fact, for single mothers who transition from no children to one child, the EITC induces a net gain in asset holdings of $\$ 800$. A striking feature of the behavior of consumption in response to the arrival of dependents is that consumption falls by less with the EITC than without it, despite the fact that mean assets are substantially lower overall in the presence of the EITC as a response to lower precautionary needs. In sum, just as with productivity uncertainty, the EITC appears to significantly mitigate demographic risk.

Table 9: Change in Consumption and Assets due to Children: EITC vs No EITC

\begin{tabular}{|l|l|r|r|r|}
\hline Variable & Model & Single, 0 Child & Single, 1 Child & Single, 2 Children \\
\hline Change in Consumption & EITC & $+\$ 2$ & $-\$ 2,000$ & $-\$ 3,400$ \\
\hline & No EITC & $-\$ 120$ & $-\$ 3,200$ & $-\$ 5,300$ \\
\hline Change in Assets & EITC & $+\$ 800$ & $+\$ 400$ & $-\$ 200$ \\
\hline & No EITC & $-\$ 800$ & $-\$ 400$ & $-\$ 1,300$ \\
\hline
\end{tabular}

\section{Concluding Remarks}

In this paper we provide, to our knowledge, the first analysis of the Earned Income Tax Credit (EITC) as an insurance program. We study the effects of the EITC on consumption variability and on labor supply for its primary target audience: unskilled single mothers. Our setting emphasizes uninsurable risks to wages and the number of dependent children a young unskilled single mother may have to provide for.

Our main finding is that the EITC is likely playing an important role in insuring the lives of its targeted population. We find that the EITC buffers households both against uncertainty in productivity (wages) and against risk with respect to demographics (dependent child care). Our analysis employs the counterfactual in which the EITC is eliminated and suggests that it may be responsible for significantly reducing the volatility of consumption of single mothers. What is more, the EITC does this while allowing households to save less and consume more.

In addition, our results suggest that the EITC has large positive effects on labor force participation and much smaller, but negative, effects on hours worked among young, unskilled single mothers. The overall effect on labor supply arises from the interaction of several factors. First, the presence of risk and relative proximity of single mothers to borrowing constraints gives them strong incentives to work hard irrespective of their productivity in order to build up precautionary balances. Second, the standard substitution effect of the EITC tends to 
encourage work as it increases the return to working for those entering the labor force. On the other hand, there are offsetting effects on labor hours conditional on working. First, there is a standard income effect from the transfer. Second, highly productive unskilled households experience the phase-out of the EITC, which generates very high marginal income tax rates for relevant income ranges. Lastly, the very insurance that EITC provides reduces the need to work in order to accumulate precautionary savings.

There are several extensions that we are considering for future work. First, it would be useful to consider broader notions of the EITC, either by extending the income ranges for EITC eligibility and/or offering larger credits and hence higher marginal tax rates. Second, our model does not differentiate between single mothers with two and three or more children. The EITC schedule, however, changed its structure to do so in tax year 2010. Third, to the extent that the extensive margin of labor supply has long been viewed as most active for the second earner in the household, it is of some interest to understand the EITC's implications for married households. Finally, recent discussions in policy arenas are entertaining the idea of making the EITC more expansive for childless earners and perhaps as a substitute for raising the national minimum wage. We leave these and other related projects for the future.

\section{References}

[1] Athreya, Kartik B. (2008). "Default, Insurance, and Debt over the Life-Cycle." Journal of Monetary Economics 55(4): 752-774.

[2] Athreya, Kartik B., and Devin Reilly. (2009). "Consumption Smoothing and the Measured Regressivity of Consumption Taxes." Economic Quarterly 95(1): 75-100.

[3] Athreya, K., Reilly, D., and Simpson, N. (2010). "The Earned Income Tax Credit, Lifecycle Income, and Marginal Tax Rates." Economic Quarterly 96(3): 229-258.

[4] Attanasio, Orazio, Hamish Low, and Virginia Sánchez-Marcos. (2005.) "Female Labor Supply As Insurance Against Idiosyncratic Risk." Journal of the European Economic Association 3(2-3): 755-764, 04/05.

[5] Attanasio, Orazio, Hamish Low, and Virginia Sanchez-Marcos. (2008). "Explaining Changes in Female Labor Supply in a Life-Cycle Model." American Economic Review 98(4): 1517-52.

[6] Bakija, J. and Slemrod, J. (2008). Taxing ourselves: A citizen's guide to the debate over taxes. MIT Press Books. 
[7] Baughman, R., and Dickert-Conlin, S. (2009). "The earned income tax credit and fertility." Journal of Population Economics 22(3): 537-563.

[8] Blank, A. (2012). "Long-term Consequences of the EITC Program." Boston College Working Paper.

[9] Blundell, R., and Pistaferri, L. (2003). "Income Volatility and Household Consumption: The Impact of Food Assistance Programs." Journal of Human Resources 38(4): 1032-50.

[10] Caputo, Richard K. (2009). "EITC \& TANF Participation among Young Adult Low-income Families." Northwestern Journal of Law and Social Policy 4: 136-149.

[11] Carroll, C., and Samwick A. (1997). "The Nature of Precautionary Wealth." Journal of Monetary Economics 40: 41-71.

[12] Chan, M. K. (2013). "A Dynamic Model of Welfare Reform." Econometrica 81(3): 9411001.

[13] Chetty, Raj, and Emmanuel Saez. (2013). "Teaching the Tax Code: Earnings Responses to an Experiment with EITC Recipients." American Economic Journal: Applied Economics $5(1): 1-31$.

[14] Citro, Constance Forbes, and Robert T. Michael. (1995). Measuring Poverty: A New Approach, National Academies Press.

[15] Cogan, J. F. (1981). "Fixed Costs and Labor Supply." Econometrica 49 (4): 945-963.

[16] Cubeddu, Luis and José-Víctor Ríos-Rull. (2003). "Families As Shocks." Journal of the European Economic Association 1(2-3): 671-682.

[17] Dickert, Stacy, Houser, Scott, and John Karl Scholz. (1995). "The Earned Income Tax Credit and Transfer Programs: A Study of Labor Market and Program Participation," NBER Chapters, in: Tax Policy and the Economy, Volume 9, pages 1-50, National Bureau of Economic Research, Inc.

[18] Domeij, David, and Martin Floden. (2006). "The Labor-Supply Elasticity and Borrowing Constraints: Why Estimates are Biased." Review of Economic Dynamics 9(2): 242-262.

[19] Eissa, Nada, and Hilary Hoynes. (2006). "Behavioral responses to taxes: Lessons from the EITC and labor supply." Tax Policy and the Economy 20: 73-110.

[20] Eissa, Nada, and Hilary Hoynes. (2011). "Redistribution and Tax Expenditures: The Earned Income Tax Credit." National Tax Journal 64 (2, Part 2), 689-730. 
[21] Eissa, N., Kleven, H. J., and Kreiner, C. T. (2008). "Evaluation of four tax reforms in the United States: Labor supply and welfare effects for single mothers." Journal of Public Economics 92(3): 795-816.

[22] Eissa, Nada, and Jeffrey B. Liebman. (1996). "Labor Supply Response to the Earned Income Tax Credit." Quarterly Journal of Economics 111(2): 605-637.

[23] Ellwood, David T., and Jeffrey B. Liebman. (2001). "The Middle Class Parent Penalty: Child Benefits in the U.S. Tax Code." NBER Working Paper No. 8031.

[24] Goldin, C., and Katz, L. F. (2008). "Transitions: Career and family life cycles of the educational elite." The American Economic Review: 363-369.

[25] Gouveia, Miguel, and Strauss, Robert P. (1994). "Effective Federal Individual Tax Functions: An Exploratory Empirical Analysis." National Tax Journal 47(2): 317-39.

[26] Grogger, J. (2004). "Welfare transitions in the 1990s: The economy, welfare policy, and the EITC." Journal of Policy Analysis and Management, 23(4): 671-695.

[27] Gruber, J. (2000). "Cash welfare as a consumption smoothing mechanism for divorced mothers." Journal of Public Economics 75(2): 157-182.

[28] Gruber, Jonathan. (2001). "The Wealth of the Unemployed: Adequacy and Implications for Unemployment Insurance." NBER Working Papers 7348.

[29] Gruber, Jon, and Emmanuel Saez. (2002). "The Elasticity of Taxable Income: Evidence and Implications." Journal of Public Economics 84 (1): 1-32.

[30] Guvenen, Fatih, Ozkan, Serdar, and Song, Jae. (2012). "The Nature of Countercyclical Income Risk." NBER Working Paper No. w18035.

[31] Heathcote, J., Storesletten, K., and Violante. G. (2009). "Quantitative Macroeconomics with Heterogeneous Households." Annual Review of Economics 1: 319-354.

[32] Hotz, V. Joseph, and Scholz, John Karl. (2001). "The Earned Income Tax Credit." NBER Working Papers No. 8078.

[33] Hotz, V. Joseph, and John Karl Scholz. (2003). "The Earned Income Tax Credit." In R. Moffitt, ed., Means-Tested Transfer Programs in the United States. Chicago: The University of Chicago Press and NBER.

[34] Hubbard, G., Skinnner, J., and Zeldes, S. (1995). "Precautionary Saving and Social Insurance." Journal of Political Economy 103: 360-99. 
[35] Huggett, M., Ventura, G., and A. Yaron. (2011). "Sources of Lifetime Inequality." American Economic Review 101(7): 2923-54.

[36] Jappelli, Tullio. (1990). "Who Is Credit Constrained in the U.S. Economy?" Quarterly Journal of Economics 105(1): 219-34.

[37] Keane, Michael, and Robert Moffitt. (1998). "A Structural Model of Multiple Welfare Program Participation and Labor Supply." International Economic Review 39 (3): 553-89.

[38] Livshits, I., MacGee, J., and Tertilt, M. (2007). "Consumer Bankruptcy: A Fresh Start." American Economic Review 97, 402-418.

[39] Low, Hamish W. (2005). "Self-Insurance in a Life-Cycle Model of Labour Supply and Savings." Review of Economic Dynamics 8(4): 945-75.

[40] Meyer, Bruce D. (2001). "Taxes, Welfare, and Work by Single Mothers." NBER Reporter Online. Cambridge, MA: National Bureau of Economic Research, www.nber.org/reporter/fall01/meyer.html.

[41] Meyer, Bruce D. (2007). "The U.S. Earned Income Tax Credit, its Effects, and Possible Reforms," Working Paper No. 0720, Harris School of Public Policy Studies, University of Chicago.

[42] Meyer, B. D., and Rosenbaum, D. T. (2000). "Making Single Mothers Work: Recent Tax and Welfare Policy and its Effects." National Tax Journal, 1027-1061.

[43] Meyer, B. D., and Rosenbaum, D. T. (2001). "Welfare, the earned income tax credit, and the labor supply of single mothers." Quarterly Journal of Economics 116(3): 1063-1114.

[44] Newbery, D. M. (1989). "Agricultural Institutions for Insurance and Stabilization," in Pranab Bardhan (ed.) The Economic Theory of Agrarian Institutions. Oxford, Clarendon Press, 267-96.

[45] Pijoan-Mas, J. (2006). "Precautionary Savings or Working Longer Hours?" Review of Economic Dynamics 9: 326-352.

[46] Romich, Jennifer L. (2006). "Difficult Calculations: Low-Income Workers and Marginal Tax Rates." Social Service Review 80(1): 27-66.

[47] Rothstein, J. (2010). "Is the EITC as Good as an NIT? Conditional Cash Transfers and Tax Incidence." American Economic Journal: Economic Policy 177-208. 
[48] Saez, E. (2010). "Do Taxpayers Bunch at Kink Points?" American Economic Journal: Economic Policy 2(3): 180-212.

[49] Scholz, John Karl, and Seshadri, Ananth. (2007). "Children and Household Wealth." University of Michigan Retirement Researh Center, Project No. UM07-12.

[50] Storesletten, K., Telmer C., and Yaron A. (2004). "Consumption and Risk-Sharing over the Life Cycle." Journal of Monetary Economics 51: 609-33.

[51] Tauchen, G. (1986). "Finite State Markov Chain Approximations to Univariate and Vector Autoregressions." Economic Letters 20: 177-181.

[52] Urban-Brookings Tax Policy Center. (2010). The Tax Policy Briefing Book. http://www.taxpolicycenter.org/briefing-book/key-elements/family/eitc.cfm 